\title{
Heliantheae (Asteraceae) na bacia do rio Paranã (GoIÁs, TOCANTINS), BRASIL ${ }^{1}$
}

\author{
João Bernardo de A. Bringel Jr. ${ }^{2,3}$ \& Taciana Barbosa Cavalcanti ${ }^{2}$
}

\begin{abstract}
Resumo
(Heliantheae (Asteraceae) na bacia do rio Paranã, (Goiás, Tocantins), Brasil) O estudo da tribo Heliantheae Cass. foi realizado na bacia do rio Paranã, nordeste de Goiás e sudeste de Tocantins, baseado em coletas e em coleções de herbários. Foram registrados 20 gêneros, 49 espécies, cinco variedades e o grupo de Calea teucriifolia . São apresentados chave de identificação, comentários para os táxons e ilustrações dos caracteres diagnósticos. Dentre os gêneros mais diversos, estão Calea (10 espécies, além do grupo de C. teucriifolia), Bidens (7) e Viguiera (6). São registrados táxons de ampla distribuição geográfica, incluindo espécies ruderais, e outros restritos à Bacia do Paranã e regiões adjacentes: Bidens edentula, Calea abbreviata, Ichthiothere connata e Wedelia souzae, endêmicos da Chapada dos Veadeiros, e Dimerostemma bishoppii, endêmica do vão do Paranã.
\end{abstract}

Palavras-chave: Compositae, Goiás, florística, Tocantins.

\section{Abstract}

(Heliantheae (Asteraceae) in the Paranã River basin (Goiás, Tocantins), Brazil) A floristic survey of tribe Heliantheae Cass. was carried out in the Paranã River basin, in northeastern Goias and southeastern Tocantins. The study was based on field work and herbarium collections. A taxonomic key and commentaries for taxa and illustrations of diagnostic characteristics are presented. Twenty genera, 49 species, five varieties, and a group of species ('Calea teucriifolia group') are recognized. The most diverse genera are Calea (10 species and the C. teucriifolia group), Bidens (7), and Viguiera (6). Taxa with broad distribution, including ruderal plants, and others restricted to the basin and neighbour areas - Bidens edentula, Calea abbreviata, Ichthiothere connata, and Wedelia souzae, endemic to the Chapada dos Veadeiros, and Dimerostemma bishoppii, endemic the Paranã valley - were recorded.

Key words: Compositae, Goiás, floristics, Tocantins.

\section{INTRODUÇÃo}

A bacia hidrográfica do rio Paranã apresenta uma flora pouco conhecida (Silva \& Scariot 2004), sendo recentemente considerada uma região de extrema importância biológica (MMA 2007) para a conservação do bioma Cerrado. Entre os anos de 1999 a 2005, o projeto "Subsídios à conservação da biodiversidade na bacia do rio Paranã, GO, TO”, financiado por MMA/PROBIO, foi executado pela Embrapa Recursos Genéticos e Biotecnologia, que realizou inventários biológicos, complementando estudos para a indicação de áreas de Unidades de Conservação e reunindo um amplo acervo botânico da região. Neste contexto, o presente trabalho tem como objetivo investigar a ocorrência da tribo Heliantheae Cass. (Asteraceae) na
Bacia do Paranã e gerar informações que auxiliem na identificação de seus táxons.

A tribo Heliantheae é circunscrita na subfamília Asteroideae (Robinson 1981; Karis \& Ryding 1994; Panero \& Funk 2008), tendo como base a corola das flores do disco com lobos curtos, apêndices das anteras ovais, constritos na base e carenados, estilete com áreas estigmáticas formando duas linhas marginais e cipselas carbonizadas (Robinson 1981). Heliantheae pode ser reconhecida por receptáculos geralmente paleáceos, anteras com tecas em sua maioria enegrecidas e pápus geralmente de aristas ou escamas (Robinson 1981; Karis \& Ryding 1994). Engloba 189 gêneros e cerca de 2.500 espécies. Baseando-se em Barroso et al. (1991) e Karis \& Ryding (1994), estima-se que ocorram, de forma natural, 39 gêneros no Brasil.

\footnotetext{
Artigo recebido em 10/2008. Aceito para publicação em 06/2009.

${ }^{1}$ Parte da dissertação de mestrado do primeiro autor, apresentada à Universidade de Brasília.

${ }^{2}$ Embrapa Recursos Genéticos e Biotecnologia, Parque Estação Ecológica, Final W5 Norte, C.P. 03372, 7770-900, Brasília, DF, Brasil.

${ }^{3}$ Autor para correspondência: jbbringel@gmail.com
} 


\section{Material e Métodos}

A bacia hidrográfica do rio Paranã, com 5.940.382 ha (Fig. 1), está localizada no nordeste de Goiás e sudeste de Tocantins, inserida na bacia do rio Tocantins $\left(12^{\circ} 14^{\prime} \mathrm{S}\right.$ a $15^{\circ} 17^{\prime}$ 'S e $46^{\circ} 03^{\prime} \mathrm{W}$ a $47^{\circ} 30^{\prime} \mathrm{W}$ ). Para verificar a distribuição geográfica e identificação dos táxons, foram visitados os herbários CEN, IBGE, MBM, NY, UB e UFU; os dados de distribuição geográfica sem referências bibliográficas estão baseados em materiais destes herbários. Foram realizadas expedições de coleta em março de 2004 e fevereiro de 2006 para complementar os dados de herbário, sendo que as equipes dos herbários CEN e IBGE já haviam realizado coletas recentes e mais amplas em virtude da participação no projeto já mencionado. Todo material coletado está depositado nos herbários CEN e UB.

A delimitação de Heliantheae utilizada é a de Karis \& Ryding (1994). Foram utilizadas diferentes literaturas de acordo com os gêneros: Baker (1884) para Riencourtia Cass. e Wedelia Jacq., Baker (1889) para Staurochlamys Baker, Sherff $(1932,1937)$ para Cosmos Cav. e

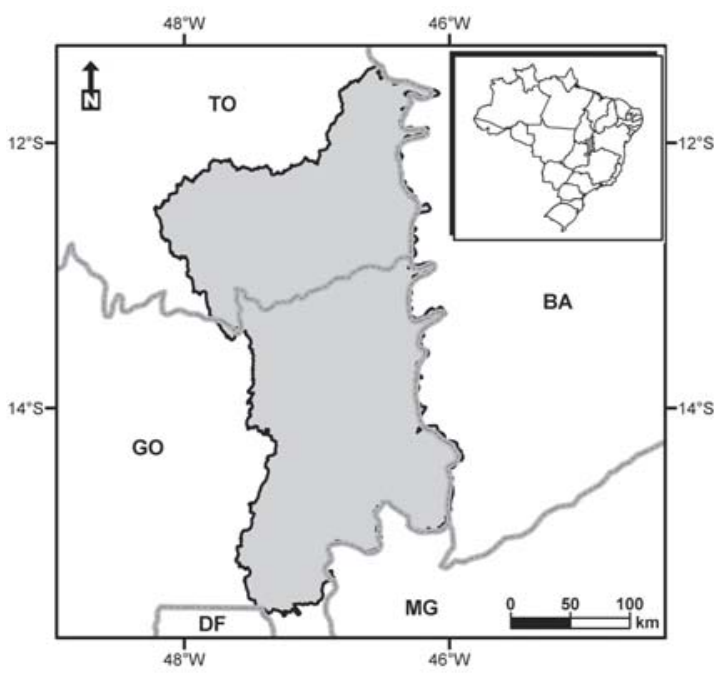

Figura 1 - Localização geográfica da bacia do rio Paranã (em cinza) nos estados de Goiás e Tocantins.

Figure 1 - Geographic localization of Paranã river basin (in grey) in Goiás and Tocantins states.
Bidens L., Powell (1965) paraTridaxL., Stuessy (1970, 1972, 1973) para Acanthospermum Schrank, Melampodium L. e Baltimora L., Jansen (1981, 1985) para Spilanthes Jacq. e Acmella Rich., Pruski \& Urbatsch $(1987,1988)$ e Urbatsch et al. (1986) para Calea L., Robinson (1978) para Blainvillea Cass., Turner (1988) para Chrysanthellum Rich., Pruski (1998) para Tilesia G. Mey., Pereira (2001) para Ichthyothere Mart., Santos (2001) para Aspilia Thouars, Arriagada (2003) para Clibadium L., Magenta (2006) para Viguiera Kunth, e Moraes et al. (2007) para Dimerostemma Cass. Descrições com material insuficiente foram complementadas com espécimes de outras áreas (identificados com asterisco na lista de exsicatas). A medida das flores corresponde apenas ao comprimento da corola (sem o ovário). Como fauce está sendo considerada toda a região mais larga do tubo da corola e o termo fauce indistinta significa ausência de um estreitamento brusco do tubo. Para descrições das inflorescências foi utilizado Rua (1999).

\section{Resultados e Discussão}

A tribo Heliantheae encontra-se representada na bacia do rio Paranã por 20 gêneros, 49 espécies, cinco variedades e um grupo de espécies reconhecido por Pruski \& Urbatsch (1987) como o grupo de Calea teucriifolia. Os gêneros mais bem representados foram Calea (10 espécies e o grupo de $C$. teucriifolia), Bidens (7) e Viguiera (6). Ocorrem táxons de ampla distribuição, restritos ao Cerrado e endêmicos da Chapada dos Veadeiros (Bidens edentula, Calea abbreviata, Ichthyothere connata e Wedelia souzae) e do vão do Paranã (Dimerostemma bishopii). Também, foram encontrados táxons de plantas que, segundo o conceito de Baker (1965), podem ser consideradas ruderais (Chrysanthellum indicum var. afroamericanum, Cosmos caudatus, Blainvillea acmella, Melampodium paniculatum e Tridax procumbens). 


\section{Chave para os táxons}

1. Capítulos disciformes. Flores marginais com corola tubulosa, às vezes inconspícua (Fig. 4a-b) . Riencourtia

2. Capítulos até $3 \mathrm{~mm}$ diâm.; apenas 1 flor pistilada R. oblongifolia

3. Folhas elípticas, oblongas ou lanceoladas, $4-18 \mathrm{~mm}$ larg. R. tenuifolia

3'. Folhas lineares, até $1 \mathrm{~mm}$ larg. 4

2'. Capítulos 4-14 mm diâm.; 2-4 flores pistiladas .... 2
4
4

4. Receptáculo plano ou convexo, sem páleas nas flores estaminadas. Flores pistiladas de corola glabra (Fig. 4a); flores estaminadas com lobos setosos.......Clibadium armanii

4'. Receptáculo cônico ou colunar, com páleas (Fig. 4c). Flores pistiladas de corola hirsuta (Fig. 4b); flores estaminadas com lobos glanduloso-pontuados... 5 5. Brácteas involucrais internas glabras Ichthyothere

6. Ramos glabros. Invólucro 8-14 mm diâm. Cipselas 5,7-6,5 mm compr. .... I. connata

6'. Ramos esparso-hirsutos ou tricomas somente na região dos nós ou na inflorescência; Invólucro 5-8 mm diâm. Cipselas 4-4,5 mm compr.

5'. Brácteas involucrais internas densamente pubescentes a estrigosas 7

7. Brácteas involucrais internas 2, estrigosas. Cipselas curto-setosas I. mollis

7’. Brácteas involucrais internas 3-4, híspidas. Cipselas glabras a glabrescentes I. integrifolia

1'. Capítulos discóides (todas as flores iguais) ou capítulos radiados com 4 ou mais flores marginais de corola liguliforme (flores do raio), às vezes limbo inconspícuo ou 3-partido (Fig. 3f-j) .... 8

8. Invólucros comprimidos, um par de brácteas involucrais orbiculares (Fig. 4f), eretas, bem maiores que as demais. Flores do raio presentes, limbo 3-partido (Fig. 3i)

Staurochlamys burchelli

8'. Invólucros não comprimidos, desprovidos de um par de brácteas orbiculares. Flores do raio ausentes ou quando presentes, limbo inteiro ou apenas o ápice lobado (Fig. 3f-h, j) ....

9. Receptáculo cônico (Fig. 4g). Cipselas longamente ciliadas (Fig. 2x-z) ............... 10 10. Capítulos radiados. Corola das flores do disco com fauce cilíndrica (Fig. 2z). Pápus com aristas delicadas, semelhantes aos cílios ......... Acmella uliginosa 10’. Capítulos discóides. Corola das flores do disco com fauce globosa ou subglobosa (Fig. 2x). Pápus com aristas robustas, levemente espessas na base

Spilanthes nervosa

9'. Receptáculo plano ou convexo. Cipselas desprovidas de cílios longos ................. 11

11. Flores do raio presentes, limbo atrofiado, mais curto que o tubo (Fig. 3j).

Blainvillea acmella

11'. Flores do raio ausentes, ou quando presentes sempre com limbo maior que o tubo (Fig. 3f-h)

12. Capítulos radiados, flores do disco funcionalmente estaminadas, gineceu não funcional, estilete indiviso

13. Cipselas do raio com pápus coroniforme, formado por aristas inconspícuas de até 0,4 mm compr. (Fig. 2b) ..... Baltimora geminata

13’. Cipselas do raio com pápus ausente 14 
14. Flores do disco com corola glanduloso-pontuada externamente (Fig. 3l). Cipselas com cerdas uncinadas (Fig. 2a) Acanthospermum australe

14'. Flores do disco com corola não glanduloso-pontuadas. Cipselas sem cerdas uncinadas (Fig. 2p, 3s) Melampodium paniculatum

12'. Capítulos discóides ou radiados, se radiados flores do disco monoclinas, gineceu funcional, estilete bifurcado .... 15

15. Pápus formado por aristas com tricomas retrorsos (Fig. 2e-f) ou pápus ausente ou inconspícuo, quando ausente, apêndices das anteras com ducto resinífero colorido (Fig. 3a-b), nunca com glândulas 16

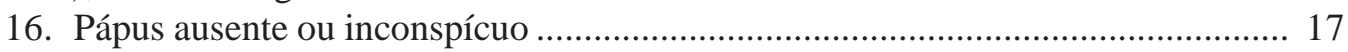

17. Folhas 2-3-pinatissectas, segmentos oblongos. Capítulos radiados. Cipselas heteromorfas (Fig. 2g-h) ...... Chrysanthellum indicum var. afroamericanum 17’. Folhas partidas, com segmentos filiformes. Capítulos discóides. Cipselas isomorfas Bidens edentula

16’. Pápus formado por aristas com tricomas retrorsos (Fig. 2e-f) 18

18. Cipselas com rostro apical onde se inserem as aristas do pápus (Fig. 2f)

Cosmos caudatus

18'. Cipselas desprovidas de rostro apical Bidens

19. Folhas partidas, segmentos filiformes

B. flagellaris

19'. Folhas com limbo inteiro ou sectado, segmentos nunca filiformes. 20 20. Cipselas hirsuto-ciliadas B. segetum var. patula 20'. Cipselas glabras ou raramente hirtelas na base 21

21. Capítulos radiados 22

22. Flores do raio com limbo até $4 \mathrm{~mm}$ compr. Pápus de 1-2 aristas eretas, 2-3 reflexas no fruto (Fig. 2e)B. riparia var. riparia 22’. Flores do raio com limbo maior que $4 \mathrm{~mm}$ compr. Pápus de 4 aristas eretas ou curvadas.

B. gardneri

21’. Capítulos discóides 23

23. Folhas inteiras, obovais, oblanceoladas ou elípticas. Corola $5,7-7,5 \mathrm{~mm}$ compr.

B. graveolens

23’. Folhas basais inteiras, ovais, as não basais 3-partidas. Corola 2,1-2,5 mm compr.

B. pilosa var. pilosa

15’. Pápus formado por cerdas plumosas, escamas, aristas sem tricomas retrorsos, ou se pápus ausente, apêndice das anteras sem ducto resinífero tingido (Fig. 3d-e), às vezes com glândulas (Fig. 3c)

24. Pápus de cerdas plumosas

Tridax procumbens

24'. Pápus somente de escamas, escamas e aristas, ou pápus ausente. 25

25. Anteras de tecas amarelas Calea

26. Capítulos discóides 27

27. Invólucro 5-7-seriado. Pápus de escamas oblongo-lanceoladas, 1,7-5 mm compr. 28

28. Capítulos com invólucro até 5 mm diâm. Pápus com escamas livres (Fig. 2i) C. fruticosa

28’. Capítulos com invólucro 8-10 mm diâm. Pápus com escamas unidas até mais da metade (Fig. $2 \mathrm{k}$ ) C. sickii

27’. Invólucro 3-4-seriado. Pápus de escamas ovais a oblongas, 0,1-0,7 mm compr. 
29. Brácteas involucrais de ápice acuminado a cuspidado (Fig. 4d). Corola atropurpúrea a vinácea C. cf. dalyi

29’. Brácteas involucrais de ápice obtuso (Fig. 4e). Corola amarela 30

30. Folhas ovais, 11-33 mm larg. Páleas do receptáculo ausentes

C. polycephala

30’. Folhas elípticas a oblongas, 4-8 mm larg. Apenas 1 pálea no receptáculo.....

26’. Capítulos radiados

Calea sp. 1

31. Folhas verticiladas, geralmente 4 por nó 31

31'. Folhas opostas C. quadrifolia

32. Capítulos solitários. Pápus com escamas linear-lanceoladas, 1-2 mm compr., simétricas (Fig. 30)

.C. abbreviata

32’. Capítulos em dicásios ou outro tipo de cimeira. Pápus com escamas ovais, arredondadas ou oblongo-ovais, até 1 mm compr. (Fig. 2l, 3p, r), quando maiores então escamas assimétricas (Fig. 2j) . 33

33. Flores do disco com lobos $0,8-1 \mathrm{~mm}$ compr., fauce mais longa que os lobos da corola (Fig. 3p); ramos do estilete de ápice agudo 34

34. Folhas com face abaxial estrigosa a hirsuta, margem serreada

C. candolleana

34'. Folhas com face abaxial glabra, margem inteira, às vezes levemente serrilhada

C. elongata

33'. Flores do disco com lobos 1,8-3,2 mm compr., fauce mais curta que os lobos da corola (Fig. 3r); ramos do estilete de ápice truncado 35

35. Brácteas involucrais externas linear-lanceoladas. Pápus assimétrico, com uma escama nitidamente maior que as demais (Fig. 2j)

C. ramosissima

35’. Brácteas involucrais externas ovais. Pápus simétrico, escamas de tamanho semelhantes (Fig. 2l) 36 36. Folhas de base obtusa, raramente cuneada. Invólucro 6-8 mm diâm. C. hypericifolia 36’. Folhas de base longo-atenuada. Invólucro (7)11-13 mm diâm..... grupo de C. teucriifolia

25'. Anteras de tecas negras 37

37. Cipselas envolvidas por polpa carnosa quando maduras. Pápus ausente ..... Tilesia baccata

37’. Cipselas nunca envolvidas por polpa carnosa. Pápus com escamas e/ou aristas, ás vezes incospícuas 38

38. Capítulos com invólucro de brácteas patentes, as externas bem maiores que as internas Dimerostemma

39. Flores do raio pistiladas D. goyazense

39'. Flores do raio neutras. 40

40. Folhas de base atenuada, curto-pecioladas, pecíolo até $4 \mathrm{~mm}$ compr. Brácteas involucrais externas lineares ou estreito-oblanceoladas, menos que $4 \mathrm{~mm}$ larg. D. grazielae

40’. Folhas de base cordada, truncada, obtusa, raramente atenuada, mas então pecíolo evidente (mais que $4 \mathrm{~mm}$ compr.). Brácteas involucrais externas oblongas, ovais ou obovais, mais que $4 \mathrm{~mm}$ larg. 41

41. Arbustos maiores que $1 \mathrm{~m}$ alt. Pedúnculos 55-150 mm. Pápus com aristas até $0,4 \mathrm{~mm}$ compr. (Fig. 2c). D. bishopii 
41’. Subarbustos cespitosos até $1 \mathrm{~m}$ alt. Pedúnculos 5-40 mm. Pápus com aristas de mais de $1 \mathrm{~mm}$ compr. (Fig. 2d) D. vestitum 38’. Capítulos com invólucro campanulado ou hemisférico, de brácteas involucrais apressas, as externas menores, ou aproximadamente do mesmo tamanho que as internas 42 42. Estilopódio arredondado, levemente alargado, facilmente destacável do nectário (Fig. 3 t). Pápus não constricto na base quando em flor (Fig. 3m) .43

43. Invólucro 2-seriado

44. Folhas ovais, elípticas, oblongas ou obovais. Brácteas involucrais estreitolanceoladas. Invólucro 20-35 mm diâm. Flores do disco com mais de 5 mm compr. V. grandiflora

44’. Folhas lineares. Brácteas involucrais ovais a elípticas. Invólucro 13-15 mm diâm. Flores do disco 3,2-4,3 mm compr. V. kunthiana 43’. Invólucro 3-4-seriado 45

45. Folhas aciculares, hifódromas, espiraladas. Invólucro 3-seriado ....... V. filifolia

45'. Folhas lineares, oblongas, elípticas, lanceoladas ou ovais; ao menos as folhas mais basais obscuro-acródromas, alterno-dísticas ou opostas. Invólucro (3) 4-seriado 46

46. Folhas frequentemente lineares, raramente lanceolato-elípticas. Capítulos em panículas corimbiformes. Páleas do receptáculo geralmente denso a esparsamente glanduloso-pontuadas no ápice V. bracteata 46’. Folhas ovais, oblongas ou elípticas. Capítulos em botrióides corimbiformes. Páleas do receptáculo desprovidas de glândulas no ápice 47 47. Cipselas 3,9-4,5 mm compr. (Fig. 2o) V. gardneri 47’. Cipselas 5-6 mm compr. (Fig. 2n) V. oblongifolia

42’. Estilopódio cilíndrico, não alargado, fortemente aderido ao nectário (Fig. 3 u-v). Pápus constricto na base quando em flor (Fig. 3k, n) . .. 48

48. Flores do raio neutras (Fig. 3f). Cipselas com cicatriz basal (Fig. 2r) .......... Aspilia

49. Invólucro 3-4-seriado 50

50. Invólucro 3-seriado, brácteas mais externas aproximadamente com o mesmo comprimento das mais internas. Apêndice da antera triangular (Fig. 3d)....

A. attenuata

50’. Invólucro 4-seriado, brácteas mais externas menores ou iguais à metade do comprimento das mais internas. Apêndice da antera oval (Fig. 3e)

A. floribunda

49’. Invólucro de brácteas 2-seriado 51

51. Flores do raio amarelas, raramente alvas, quando alvas limbo maior que 1,6 cm compr. Cipselas maduras obovóides ou amplo-obovóides, 3,5-4,6 mm compr. A. foliacea

51'. Flores do raio alvas, limbo até 1,2 cm compr. Cipselas maduras elipsóides 8,4-9,5 mm compr.

A. leucoglossa

48'. Flores do raio pistiladas (Fig. 3g). Cipselas nunca com cicatriz basal (Fig. 2s-v).......

Wedelia

52. Folhas não glânduloso-pontuadas W. modesta

52'. Folhas glanduloso-pontuadas na face abaxial . 53

53. Folhas sésseis. Flores do raio alvas (levemente amareladas quando secas) W. pallida 
53’. Folhas raramente sésseis, pecíolo até $8 \mathrm{~mm}$ compr. Flores do raio amarelas

54. Capítulo sempre 1 por nó. Cipselas de superfície tuberculada a lisa, quando lisa então alas inconspícuas, ca. 0,1 mm larg. (Figs. 2t-v) W. souzae

54’. Capítulos (1--)3-5 por nó. Cipselas de superfíce lisa, não aladas (Fig. 2s) ........ W. regis

1. Acanthospermum australe (Loefl.) Kuntze, Revis. gen. pl. 1: 303. $1891 . \quad$ Fig. 2a; 31

Ervas prostradas, hirsutas. Folhas opostas, inteiras, elípticas 12-33×8-22 mm, híspidas, glanduloso-pontuadas, sésseis, ápice obtuso, base atenuada, margem serreada a crenada. Capítulos radiados, em cimeiras dicotômicas, 6-8 mm diâm., pedúnculo 8-23 mm compr.; invólucro hemisférico, 2-seriado; brácteas involucrais externas foliáceas, subiguais, ovais a elípticas, setosas, ápice obtuso, ciliado, as internas fundidas por completo às paredes das cipselas; receptáculo plano, paleáceo; páleas conduplicadas, oblongas, ápice obtuso, longociliado, face dorsal glanduloso-pontuada. Flores do raio pistiladas, levemente amareladas, glabras, gladuloso-pontuadas, tubo inconspícuo, limbo ca. 1,5 mm compr.; flores do disco estaminadas, leve-amareladas, ca. $2 \mathrm{~mm}$ compr., fauce campanulada, glabra, glandulosopontuada, lobos ca. 0,6 mm compr., glandulosopontuados. Cipselas do raio oblongo-fusiformes, 6-11 × $-3 \mathrm{~mm}$, glanduloso-pontuadas, cerdas uncinadas; pápus ausente.

Material examinado: GOIÁs: Campos Belos, IV.2001, fl. efr.,Fonseca et al. 2514 (CEN, IBGE, UB).

América do Sul, introduzida nas Antilhas e Havaí. Sul dos Estados Unidos (Blake 1921). Cerrado s.s. Flores de janeiro a abril.

2. Acmella uliginosa (Sw.) Cass., Dict. sci. nat. (ed. 2) 24: 331. $1822 . \quad$ Fig. 2z; 4g

Ervas ca. $70 \mathrm{~cm}$ alt., glabras a esparsohirsutas, tricomas glandulares, não captados. Folhas opostas, inteiras, estreito-ovais a lanceoladas, 11-54 × 3-23 mm, estrigosas, pecíolo 3-6 mm compr., ápice agudo a obtuso, base atenuada a obtusa, margem serrilhada a inteira. Capítulos radiados em dicásios ou solitários, 5-8 mm diâm., pedúnculo 2,4-5 cm compr.; invólucro hemisférico, 2-seriado; brácteas involucrais escariosas, subiguais, obovais a oblanceoladas, glabrescentes, ápice agudo a obtuso, ciliado; receptáculo plano, paleáceo; páleas côncavas, oblanceoladas, ápice obtuso, face dorsal glabra. Flores do raio pistiladas, amareladas, tubo ca. $1 \mathrm{~mm}$ compr., setoso, limbo ca. $2 \mathrm{~mm}$ compr., glabro; flores do disco monoclinas, amareladas, ca. 1,5 mm compr., fauce cilíndrica, pouco mais larga que o tubo, glabra, lobos ca. 0,3 mm compr., glabros. Cipselas elípticas a oblongas, ca. $1,7 \times 0,75 \mathrm{~mm}$, glabras, longo-ciliadas; pápus 2-aristado, aristas eretas, finas, semelhantes aos cílios.

Material examinado: GOIÁS: São Domingos, VI.2000, fl.e fr., Oliveira et al. 1103 (IBGE). TOCANTINS: Arraias, II.1994, fl.e fr., Hatschbach et al. 60413 (MBM).

Pantropical. Venezuela, Brasil, América Central, África, Indonésia e Malásia. Mata de galeria, cerrado com solo arenoso. Flores durante todo o ano (Jansen 1985). Embora, no material examinado, só tenham sido observados espécimes de capítulos radiados, Jansen (1985) afirma que a espécie pode apresentar capítulos discóides.

3. Aspilia attenuata (Gardner) Baker in Martius \& Eichler, Fl. bras. 6(3): 199. 1884.

Fig. 2r; 3d, f, k

Arbustos ou subarbustos pouco ramificados, 0,8-1,5 m alt., glabros a hirsutos. Folhas opostas, inteiras, lanceoladas 49-108× 9-41 mm, estrigosas a híspidas, sésseis, ápice agudo, base obtusa a cuneada, margem inteira a serreada. Capítulos radiados, em tirsóides, 7-11 mm diâm., pedúnculo 6-86 mm compr.; invólucro campanulado, 3-seriado; brácteas involucrais foliáceas, subiguais ovais, estrigosas, ápice agudo a obtuso; receptáculo plano, paleáceo; páleas conduplicadas, oblongas, ápice mucronado, ciliado, face dorsal glabra. Flores do raio neutras, amarelas, tubo 1-2 mm compr., hirsuto; limbo 8-10 mm compr., 

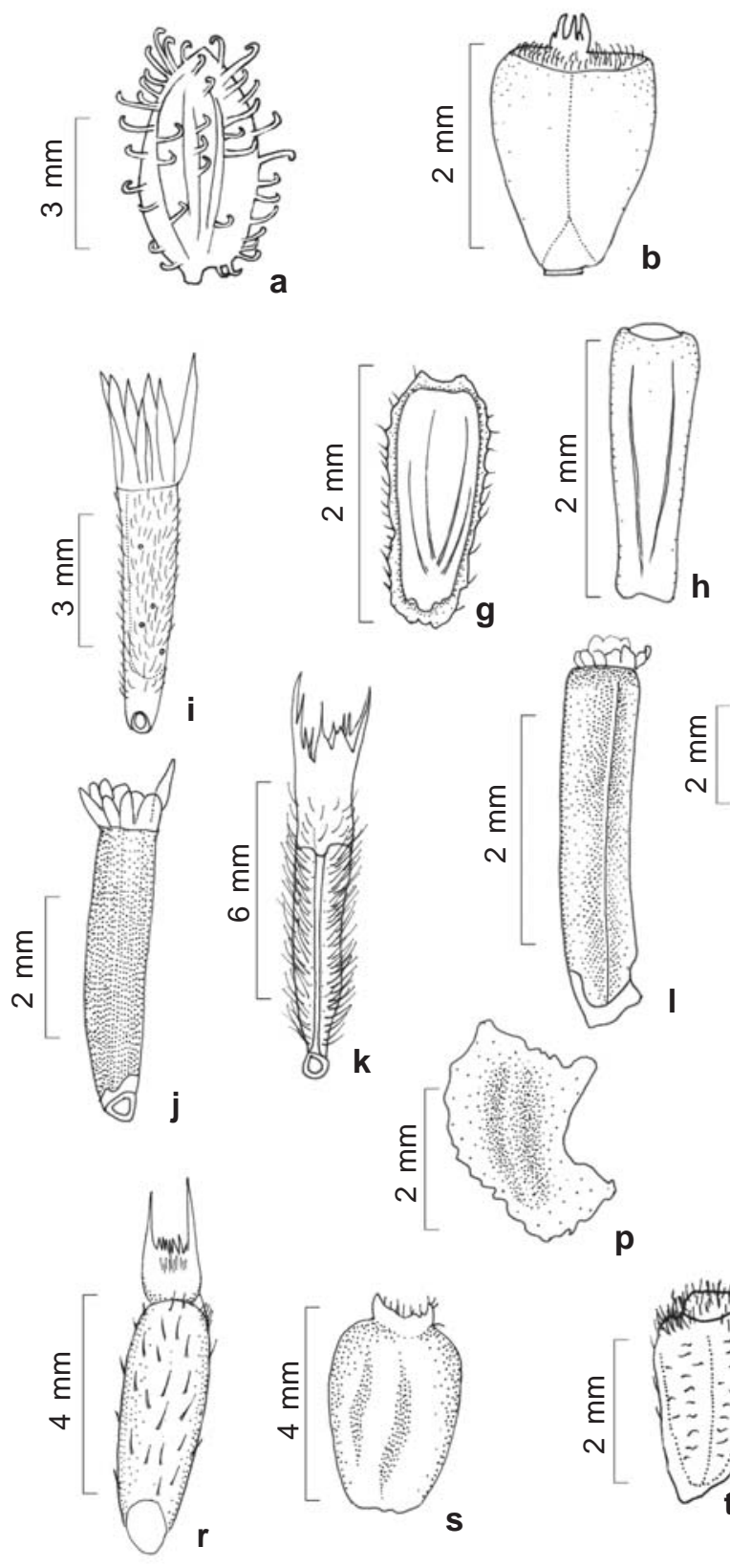
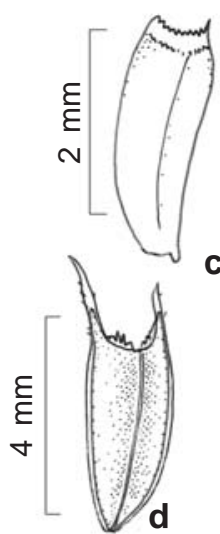

C $\stackrel{\S}{\Xi}$
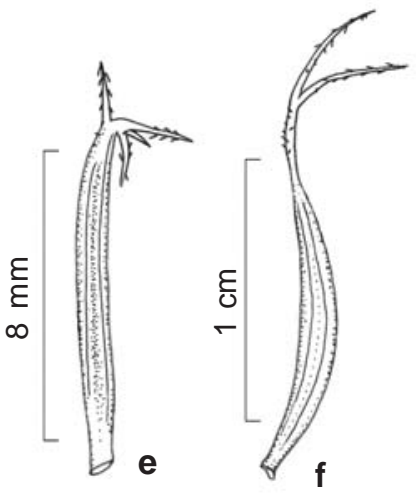

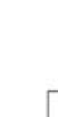
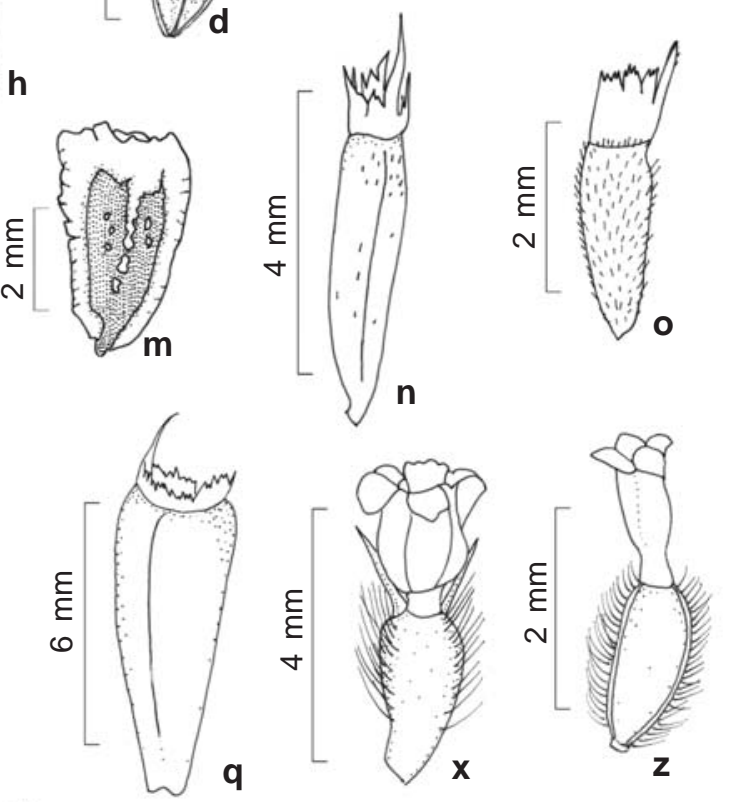
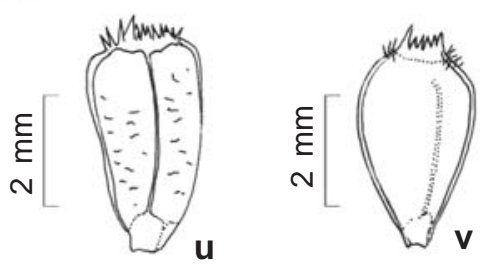

Figura 2 - Heliantheae na bacia do Rio Paranã (GO, TO). Cipselas (a-v) e flores (x-z). a. Acanthospermum australe; b. Baltimora geminata; c.Dimerostemma bishopii; d. Dimerostemma vestitum; e. Bidens riparia var. riparia; f. Cosmos caudatus; g-h. Chrysanthellum indicum var. afroamericanum; i. Calea fruticosa; j. Calea ramosissima; k. Calea sickii; l. Calea hypericifolia; m. Dimerostemmas goyazense; n. Viguiera oblongifolia; o. Viguiera gardnerii; p. Melampodium paniculatum; q. Viguiera grandiflora; r. Aspilia attenuata; s. Wedelia regis; t-v. Wedelia saouzae; x. Spilanthes nervosa; z. Acmella uliginosa.

Figure 2 - Heliantheae in Paranã river basin (GO, TO). Cypselas (a-v) and flowers (x-z). a. Acanthospermum australe; b. Baltimora geminata; c. Dimerostemma bishopii; d. Dimerostemma vestitum; e. Bidens riparia var. riparia, f. Cosmos caudatus; g-h. Chrysanthellum indicum var. afroamericanum; i. Calea fruticosa; j. Calea ramosissima; k. Calea sickii; l. Calea hypericifolia; m. Dimerostemmas goyazense; n. Viguiera oblongifolia; o. Viguiera gardnerii; p. Melampodium paniculatum; q. Viguiera grandiflora; r. Aspilia attenuata; s. Wedelia regis; t-v. Wedelia saouzae; x. Spilanthes nervosa; z. Acmella uliginosa. 


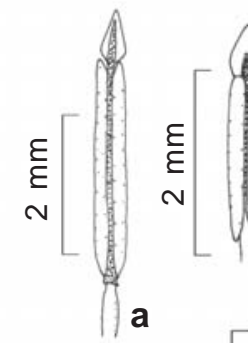

$\int_{b}$
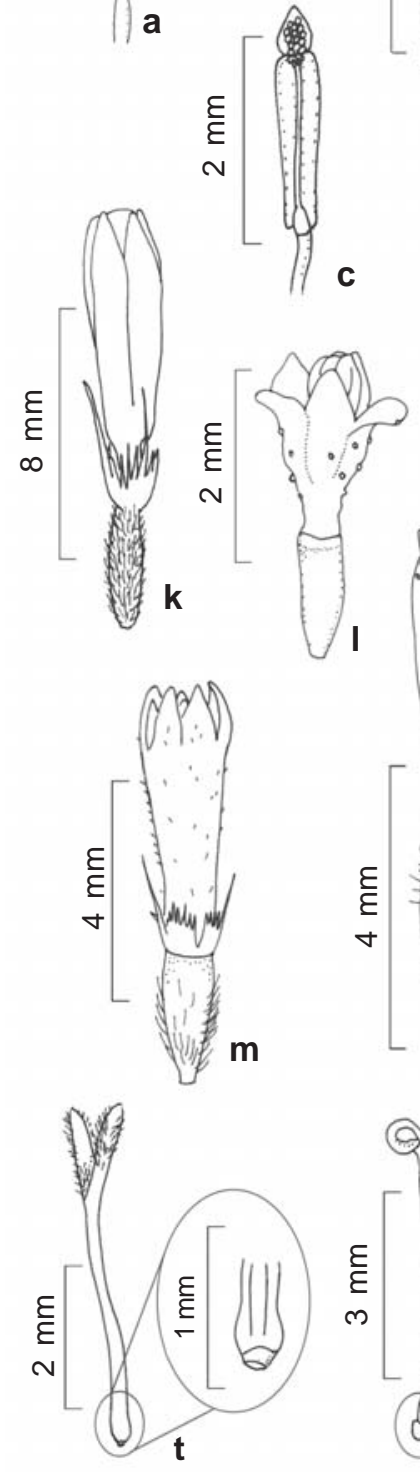
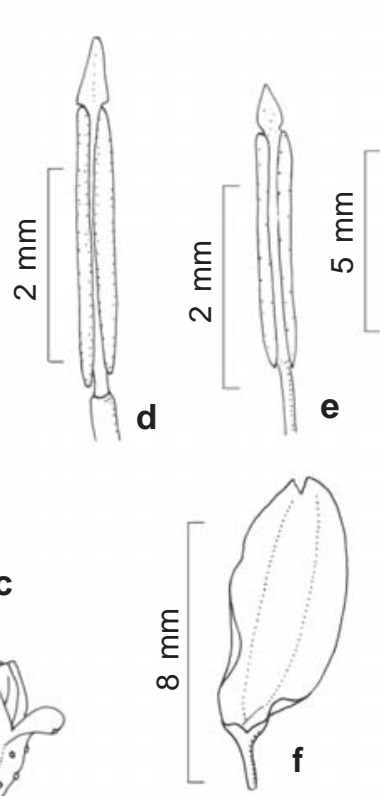
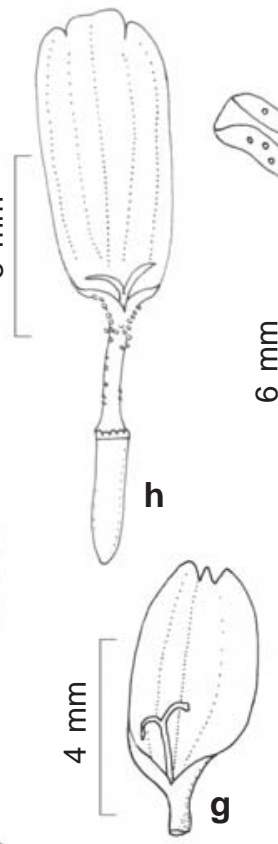

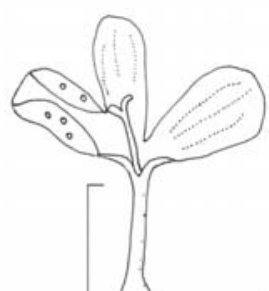

$\stackrel{\varepsilon}{\varepsilon}$

$\varepsilon$
$\mathcal{1}$
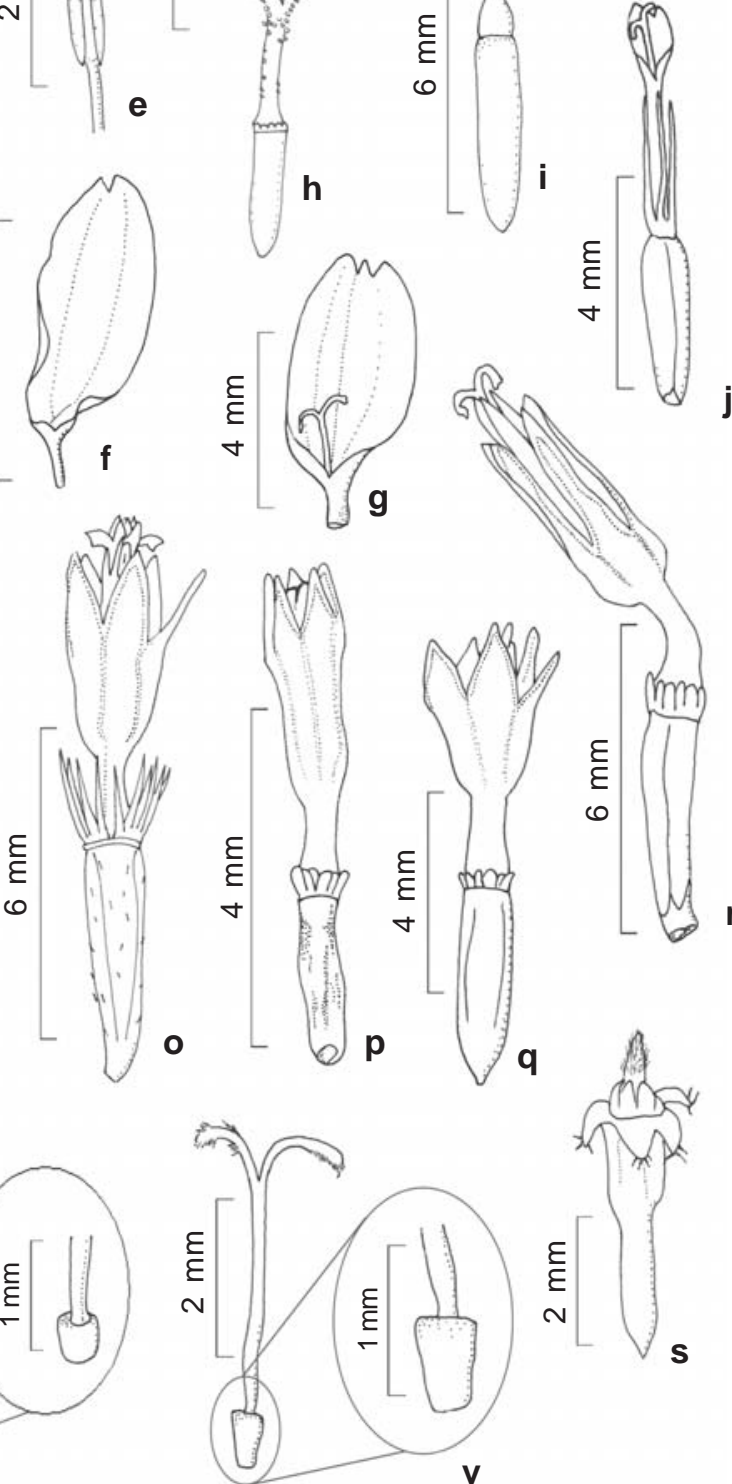

Figura 3 - Heliantheae na bacia do Rio Paranã (GO, TO). Estames (a-e), corola das flores do raio (f-g), flores do raio (h-j), flores (k-s) e estilete e estilopódio t-v). a. Bidens graveolens; b. Cosmos caudatus; c. Wedelia regis; d. Aspilia attenuata; e. Aspilia floribunda; f.Aspilia attenuata; g. Wedelia pallida; h. Calea candolleana; i.Staurochlamys burchelli; j. Blainvillea acmella; k.Aspilia attenuata; l. Acanthospermum australe; m. Viguiera bracteata; n. Wedelia pallida; o. Calea abbreviata; p.Calea candolleana; q. Calea sp.1; r. Calea hypericifolia; s. Melampodium paniculatum; t. Viguiera bracteata; u. Aspilia foliacea; v. Wedelia regis.

Figura 3 - Heliantheae in Paranã river basin (GO, TO). Stamens (a-e), ray flower's corolla (f-g), ray flower (h-j), flowers (k-s) and style and style base t-v). a. Bidens graveolens; b. Cosmos caudatus; c. Wedelia regis, d. Aspilia attenuata; e. Aspilia floribunda, f. Aspilia attenuata; g. Wedelia pallida; h. Calea candolleana; i. Staurochlamys burchelli; j. Blainvillea acmella, k. Aspilia attenuata; l. Acanthospermum australe; m. Viguiera bracteata; n. Wedelia pallida; o. Calea abbreviata; p. Calea candolleana; q. Calea sp.1; r. Calea hypericifolia; s. Melampodium paniculatum; t. Viguiera bracteata; u. Aspilia foliacea; v. Wedelia regis. 
estriguloso nas nervuras da face abaxial; flores do disco monoclinas, amarelas, 5-7,5 mm compr., fauce estreito-infundibuliforme, glabrescente, lobos 1-1,5 mm compr., pubérulos. Cipselas oblongas, achatadas 4,86,5 × 1,5-2 mm, setosas a seríceas; pápus $2-$ 3-aristado; aristas eretas, 2-4 $\mathrm{mm}$, escamas em estrutura coroniforme,1-1,5 mm compr.

Material selecionado: TOCANTINS Arraias, III.2006, fl. e fr., Bringel \& Barbosa 281 (CEN, UB).

Brasil: PA, TO, MA, MT, GO, MG e DF (Santos 2001). Cerrado e campo sujo. Flores e frutos de março a maio.

4. Aspilia floribunda (Gardner) Baker in Martius \& Eichler, Fl. bras. 6(3): 198. 1884.

Fig. 3e

Arbustos 1-1,5 m alt., ramificados; estrigulosos a estrigosos. Folhas opostas, inteiras, lineares a estreito-lanceoladas, 7-105 $\times$ 4-13 mm, estrigosas, sésseis, ápice agudo, base cuneada, margem serrilhada a serreada. Capítulos radiados, em dicásios, 6-10 mm diâm., sésseis ou pedúnculo até 7,5 cm compr.; invólucro campanulado, 4-seriado; brácteas involucrais foliáceas a escariosas, desiguais, as internas gradativamente maiores que as externas, ovais a oblongas, estrigosas a ciliadas, ápice agudo a cuspidado; receptáculo convexo, paleáceo; páleas conduplicadas estreitoelípticas, ápice agudo, ciliado, face dorsal estrigulosa no ápice. Flores do raio neutras, amarelas, glabras, tubo 2,5-3,5 mm compr., limbo 8-12,5 mm compr.; flores do disco monoclinas, amarelas, 4,7-5,6 mm compr., fauce infundibuliforme a subcilíndrica, glabra, lobos 0,5-1 mm compr., glabrescentes a pubérulos. Cipselas oblanceoladas a oblongas, 3,2-5,4 × ca. $1 \mathrm{~mm}$, setosas; pápus 0-2aristado, aristas eretas, desiguais, inconspícuas ou até $1,7 \mathrm{~mm}$ compr., escamas em estrutura coroniforme, ca. 0,5 mm compr.

Material selecionado: GOIÁS: Alvorada do Norte, III.1979, fl. e fr., Hatschbach et al. 42014 (MBM).

Brasil: PR, SP, MS, MG MG, GO, TO e PI (Santos 2001). Cerrado s.s. Flores e frutos de janeiro a maio.
5. Aspilia foliacea (Spreng.) Baker in Martius \& Eichler, Fl. bras. 6(3): 199. $1884 . \quad$ Fig. 3u

Ervas a subarbustos cespitosos, 6-30 cm alt., estrigosos a hirsutos. Folhas opostas, inteiras, estreito-oblongas, elípticas, lanceoladas ou ovais, $20-60 \times 3-16 \mathrm{~mm}$, estrigosas a híspidas, sésseis a subsésseis, ápice agudo, base cuneada a obtusa, margem inteira a serreada. Capítulos radiados, solitários ou raramente em dicásios simples, 1,7-2,5 cm diâm., pedúnculo 2,1-6,8 cm compr.; invólucro campanulado, 2-seriado; brácteas involucrais foliáceas, levemente desiguais, as internas pouco menores, lanceoladas, híspidas a estrigosas, ápice agudo; receptáculo convexo, paleáceo; páleas conduplicadas, lanceoladas, ápice acuminado a caudado, face dorsal pubescente. Flores do raio neutras, amarelas a alvas, tubo ca. $2 \mathrm{~mm}$ compr., glabro ou esparso-setoso, limbo 2,3-2,7 cm compr. glabro ou pubérulo na face abaxial; flores do disco monoclinas, amarelas a alvas, 7-7,5 mm compr., fauce cilíndrica a estreitoinfundibuliforme, glabra, lobos ca. $1 \mathrm{~mm}$ compr., inconspicuamente pubérulos. Cipselas obovóides ou amplo-obovóides. 3,5-4,6 × 2,34,3 mm, hispidulosas; pápus 2-3-aristado; aristas eretas, 0,5-2 mm compr., escamas em estrutura coroniforme ca. 0,5 mm compr.

Material selecionado: GOIÁS: Campos Belos, X.2001, fl., Mendonça et al. 4539 (IBGE). TOCANTINS: Dianópolis, IX.2003, fl. e fr., Cavalcanti et al. 3444 (CEN).

Brasil: DF, GO, MT, MS, MG, SP, PR, RS (Santos 2001). Cerrado s.s., cerrado rupestre, campo limpo. Flores de setembro a novembro, no início da estação chuvosa.

Santos (2001) registrou Aspilia foliacea apenas com flores amarelas. Foram observados, no entanto, espécimes com as flores alvas, os quais podem ser confundidos com $A$. leucoglossa. Neste trabalho, utilizou-se o tamanho das flores do raio, além do tamanho e forma das cipselas maduras para separá-las. No entanto, como foram observados poucos espécimes de $A$. leucoglossa e as duas espécies dificilmente são coletadas com cipselas maduras, 
recomenda-se um estudo com mais exemplares e observações em campo a fim de melhor esclarecer os limites entre essas duas espécies.

6. Aspilia leucoglossa Malme, Kongl. Svenska Vetensk. Acad. Handl. 32(5): 62. 1889.

Ervas a subarbustos, $20-40 \mathrm{~cm}$ alt., simples a pouco ramificados; glabras a hirsutas. Folhas opostas, inteiras, ovais a lanceoladas 3,5-9,1 × 1,6-5 cm, estrigosas, sésseis, ápice agudo, base obtusa a cuneada, margem inteira a serreada. Capítulos radiados, solitários ou em dicásios simples, 1,5-2 cm diâm., pedúnculo 1,5-5,2 cm compr.; invólucro campanulado, 2seriado; brácteas involucrais foliáceas, levemente desiguais, as internas pouco menores, ovais a oblongo-lanceoladas, estrigosas, ápice agudo; receptáculo plano, paleáceo, páleas conduplicadas, oblongas, ápice agudo a obtuso, face dorsal pruinosa. Flores do raio neutras, alvas, tubo $3-6 \mathrm{~mm}$ compr., glabro; limbo 1-1,2 cm compr., esparso-setoso na face abaxial; flores do disco monoclinas, alvas, 7,5-9 mm compr., fauce infundibuliforme, glabra, lobos ca. $1 \mathrm{~mm}$ compr., pubérulos externamente. Cipselas quando imaturas oblongas e seríceas, quando maduras elipsóides 8,4-9,5 × 3,2-4,8 mm, esparso-setosas; pápus 2-aristado, aristas eretas, 2-3 mm compr., escamas em estrutura coroniforme, 0,5-1 mm compr.

Material examinado: GOIÁS: Posse, III.2001, fl. e fr., Aparecida-Silva et al. 4901 (IBGE). TOCANTINS: Dianópolis, XII.1991, fl., Fonseca et al. 26 (IBGE).

Brasil: RO, TO, BA, PI, MT, GO e MS (Santos 2001). Cerrado s.s. e campo. Flores de fevereiro a março.

7. Baltimora geminata (Brandegee) Stuessy, Fieldiana, Bot. 36(5): 42. $1973 . \quad$ Fig. 2b

Ervas ca. 1,5 m alt., estrigosas. Folhas opostas, inteiras, ovais a lanceoladas, 7-14 $\times$ 3-8 cm, estrigosas, glanduloso-pontuadas na face abaxial, pecíolo 8-26 mm compr., ápice caudado, base cuneada; margem serreada. Capítulos radiados, em dicásios, 4-6 mm diâm., sésseis ou com pedúnculo até 2,9 cm compr.; invólucro campanulado a hemisférico, 2seriado; brácteas involucrais foliáceas, subiguais, ovais, setosas, pruinosas a glanduloso-pontuadas, ápice acuminado; receptáculo plano, paleáceo; páleas conduplicadas, oblanceoladas, ápice mucronado, ciliado, face dorsal com tricomas inconspícuos. Flores do raio pistiladas, amarelas, tubo 1,2-1,4 mm compr., glabro, limbo 3,5-4 $\mathrm{mm}$ compr., setoso e glanduloso-pontuado na face abaxial; flores do disco estaminadas, amarelas, 3-4 mm compr.; fauce indistinta, glanduloso-pontuada, lobos ca. 0,5mm compr., ciliados, glanduloso-pontuados. Cipselas obpiramidais, 2,4-2,6 × 1,7-1,8 mm, ápice setoso; pápus coroniforme, aristas eretas, até 0,4 mm compr.

Material examinado: GOIÁS: São Domingos, III.2004, fl. e fr.,Amaral-Santos et al. 2408 (CEN).

México, Cuba, Haiti e Curaçao, Venezuela, Equador, Colômbia, Bolívia, Peru, Brasil e Paraguai (Stuessy 1973). Mata estacional decidual. Flores e frutos em março.

8. Bidens edentula G. M. Barroso, Sellowia 26: 103.1975.

Arbustos até 1,5 m alt., glabros. Folhas opostas, pinatipartidas, segmentos filiformes, 50-290 × 0,5-0,7 mm, glabras, sésseis, ápice mucronado, base truncada, margem inteira. Capítulos discóides, em corimbos laxos, 8-12 mm diâm., pedúnculo 6-8 cm compr.; invólucro campanulado a hemisférico, 2-seriado; brácteas involucrais escariosas, desiguais, as externas bem menores, espatuladas, ciliadas, ápice obtuso a arredondado, as internas elípticas, glabras, ápice agudo; receptáculo plano, paleáceo; páleas, planas, oblongas, ápice agudo, face dorsal glabra. Flores monoclinas, amarelas, 6-6,5 mm compr., fauce infundibuliforme, glabra, lobos 0,7-1 mm compr., glabros;. Cipselas não vistas; pápus ausente.

Material examinado: GOIÁS: Alto Paraíso de Goiás, III.1973, fl., Anderson et al. 7195 (NY).

Restrita à Chapada dos Veadeiros e rara em herbários. Campo rupestre. Flores em março. 
9. Bidens flagellaris Baker in Martius \& Eichler, Fl. bras. 6(3): 248. 1884.

Ervas $40 \mathrm{~cm}$ alt., pouco ramificadas, glabras. Folhas opostas, simples ou partidas, glabras, sésseis, segmentos filiformes $6-50 \times$ ca. 0,5 mm, ápice agudo a truncado, base truncada, margem inteira. Capítulos discóides, em corimbos laxos, ca. 11 mm diâm., pedúnculo 6-62 mm compr.; invólucro campanulado, 2seriado; brácteas involucrais escariosas, desiguais, as externas bem menores, lineares, glabras, ápice agudo, as internas oblongolanceoladas, glabras, ápice obtuso a agudo; receptáculo plano, paleáceo; páleas planas, oblongas, ápice obtuso, face dorsal glabra. Flores monoclinas, amarelas, 6,5-7,4 mm compr., fauce cilíndrica, glabra, lobos ca. 0,7 mm compr., glabros. Cipselas oblongofusiformes, ca. $12 \times 1,5 \mathrm{~mm}$, glabra; pápus $3-$ 4-aristado, aristas eretas, 2,7-5 mm compr.

Material examinado: GOIÁS: Posse, IV.1966, fl. e fr., Ir win et al. $14592(\mathrm{NY})$.

Brasil: MG e GO (Sherff 1937). Cerrado s.s. Flores e frutos em abril.

10. Bidens gardneri Baker in Martius \& Eichler, Fl. bras. 6(3): 246. 1884.

Subarbustos $0,5-0,8 \mathrm{~m}$ alt., eretos, hirsutos. Folhas opostas, inteiras ou pinatissectas, 25-70 × 19-42 mm, estrigosas, sésseis, segmentos ovais a lanceolados, ápice agudo, base atenuada, margem serreada. Capítulos radiados, em dicásios, ca. $8 \mathrm{~mm}$ diâm., pedúnculos 11,2-19,2 cm compr.; invólucro hemisférico, 2-seriado; brácteas involucrais escariosas, desiguais, as externas nitidamente mais estreitas, lineares, estriglosas, ápice obtuso, as internas oblongo-lanceoladas, pubérulas, ápice agudo; receptáculo plano, paleáceo; páleas planas, lanceoladas, ápice agudo, face dorsal glabra. Flores do raio neutras, amarelas, glabras, tubo ca. $1 \mathrm{~mm}$ compr., limbo ca. 7,3 mm compr.; flores do disco monoclinas, amarelas, 4-5,5 mm compr., fauce infundibuliforme, glabra, lobos ca. $1 \mathrm{~mm}$ compr., glabros. Cipselas oblongo-fusiformes 8,7-9,7 ×1-1,3 mm, glabras; pápus 4-aristado, aristas eretas, 1,3-2,3 mm compr.
Material examinado: GOIÁS: Posse, II.1981, fr., King \& Bishop 8798 (UB).

Paraguai e Brasil: Sul, Sudeste, CentroOeste e BA (Sherff 1937). Cerrado s.s. Flores e frutos em fevereiro.

11. Bidens graveolens Mart., Isis (Oken) 1824: 590. 1824.

Fig. 3a

Subarbustos $0,6-1,1 \mathrm{~m}$ alt., cespitosos, glabros. Folhas opostas, inteiras, obovais, oblanceoladas ou elípticas, 44-80×5-22 mm, glabras, sésseis, ápice acuminado a cuspidado, base cuneada, margem serrilhada a serreada. Capítulos discóides, em dicásios, 6-11 mm diâm.; pedúnculo 7-20 mm compr.; invólucro cilíndrico a campanulado, 2-seriado; brácteas involucrais escariosas, desiguais, as externas menores, lineares, glabras, ápice obtuso, as internas oblongas, glabras, ápice agudo; receptáculo plano, paleáceo; páleas planas, oblongas, ápice obtuso, face dorsal glabra. Flores monoclinas, amarelas, 5,7-7,5 mm compr., fauce cilíndrica, glabra, lobos 0,7-1 mm compr. glabros. Cipselas oblongas, 13-15,4× 1-1,2 mm, glabras; pápus 2-aristado, aristas eretas 2,5-3,2 mm compr.

Material selecionado: GOIÁs: Alto Paraíso de Goiás, III.1995, fl. e fr., Cavalcanti et al. 1326 (CEN). Brasil: GO, MG, SP e DF (Sherff 1937). Cerrado s.s. Flores e frutos de fevereiro a abril.

12. Bidens pilosa L. var. pilosa, Sp. pl. 2: 832. 1753.

Ervas até $1 \mathrm{~m}$, alt. eretas, glabras, pruinosas. Folhas opostas, as basais inteiras, as demais tripartidas, segmentos ovais, 6,5-11,5 × 2,6$4,3 \mathrm{~cm}$, glabras, sésseis ou pecíolo até $1,8 \mathrm{~cm}$ compr., ápice mucronado, base obtusa, margem serreada a denteada. Capítulos discóides, em tirsóides laxos, 5-8 mm diâm.; pedúnculo 315 cm compr.; invólucro campanulado, 2-seriado; brácteas involucrais escariosas, desiguais, as externas menores, lineares, glabras, ápice arredondado, as mais internas lanceoladas, glabras, ápice agudo; receptáculo plano, paleáceo; páleas planas oblongo-lanceoladas, ápice obtuso, face dorsal glabra. Flores monoclinas, levemente amareladas $2-2,5 \mathrm{~mm}$ 
compr., fauce cilíndrica, glabra, lobos 0,3-0,5 $\mathrm{mm}$ compr., glabros. Cipselas oblongofusiformes, $11-13 \times$ ca. $1 \mathrm{~mm}$, glabra; pápus 2-3-aristado, aristas eretas, 2-3 mm compr.

Material examinado: GOIÁS: Monte Alegre, IV.2000, fl. e fr., Mendonça et al. 4140 (CEN, IBGE).

Regiões tropicais e subtropicais (Sherff 1937). Mata estacional decidual. Flores e frutos em abril.

13. Bidens riparia Kunth var. riparia. Nov. gen. sp. 4: 236. 1820. Fig. 2e

Ervas 0,5-1 m alt., eretas, glabras. Folhas opostas, bipinatissectas, estrigulosas, pecíolo 2,5-3,5 cm compr., segmentos ovais a lanceolados, 20-47 × 9-19 mm, ápice mucronado, base obtusa, atenuada, margem serreada. Capítulos radiados, em dicásios, 510 mm diâm.; pedúnculo 9-15 cm compr.; invólucro campanulado, 3-seriado; brácteas involucrais escariosas, desiguais, as mais externas, mais compridas, lineares, glabras, ápice obtuso, as internas linear-lanceoladas, glabras, ápice obtuso; receptáculo plano, paleáceo; páleas planas, oblongas, ápice obtuso, face dorsal glabra. Flores do raio neutras, amareladas, glabras, tubo ca. 0,8 mm compr., limbo ca. 2,7 mm compr.; flores do disco monoclinas, amarelas, ca. 2,7 mm compr., fauce cilíndrica, glabra, lobos ca. 0,4 mm compr., glabros. Cipselas oblongas a fusiformes, $6-10 \times 0,9 \mathrm{~mm}$, glabras ou hirtelas na base; pápus 3-5-aristado, aristas 1-2 eretas e 2-3 reflexas, 1-2 mm compr.

Material examinado: GOIÁS: Monte Alegre, IV.2000, fl. e fr., Fonseca et al. 2261 (IBGE).

México, Guatemala, Costa Rica, Peru e Brasil (Sherff 1937). Mata estacional decidual. Flores e frutos em abril.

14. Bidens segetum Mart. ex Colla var. patula (Gardner) Sherff, Field Mus. Nat. Hist., Bot. Ser. 16: 197. 1937.

Subarbustos até $3 \mathrm{~m}$ alt., escandentes, glabros. Folhas opostas, inteiras, ovallanceoladas, $4,7-8,6 \times 1,5-3,5 \mathrm{~cm}$, glabrescentes, estrigulosas ou setosas, pecíolo 7-25 mm compr., ápice mucronado, base decorrente, margem serreada. Capítulos radiados, em tirsóides, 7-16 mm diâm., pedúnculo 2-4,5 cm compr.; invólucro campanulado, 2-seriado; brácteas involucrais escariosas, desiguais, as externas lineares, ciliadas ou hirsutas, ápice agudo; as internas elípticas a lanceoladas, ciliadas, ápice agudo, receptáculo plano, paleáceo; páleas planas, oblongo-lanceoladas, ápice agudo, face dorsal glabra. Flores do raio neutras, amarelas, glabras, tubo ca. 1,5 mm compr., limbo 1,5-1,8 cm compr; flores do disco monoclinas, amarelas, 6,2-8,2 mm compr., fauce cilíndrica, glabra, lobos 1-1,3 mm compr. glabros. Cipselas oblongas, $12-13 \times$ ca. $1 \mathrm{~mm}$, hirsutociliadas, glabras; pápus 2-aristado, aristas eretas, 5-6 mm compr.

Material examinado: GOIÁS: Cavalcante, III.1973, fl., Anderson et al. 7310 (NY).

Peru, Bolívia e Brasil: GO, MG e PR (Sherff 1937). Mata de galeria. Flores em março.

15. Blainvillea acmella(L.) Philipson, Blumea 6(2): 350. 1950. Fig. 3j

Subarbustos ca. 1,6 m alt., hirsutos. Folhas opostas, inteiras, ovais, 8,5-11,5×2,5$5,2 \mathrm{~cm}$, seríceas a tomentosa, às vezes glanduloso-pontuadas, pecíolo 8-21 mm, ápice cuspidado a caudado, aguda a atenuada, serreada a denteada. Capítulos radiados, em tirsóides, 4-11 mm diâm., pedúnculo 5-28 mm; invólucro cilíndrico a campanulado, 2-seriado; brácteas involucrais escariosas, subiguais, lanceoladas, estrigosas a glabras, ápice agudo; receptáculo plano, paleáceo; páleas côncavas, oblongas, ápice denteado a lacerado, ocasionalmente assimétrico, face dorsal com tricomas inconspícuos.. Flores do raio pistiladas, alvas, glabras, glanduloso-pontuadas, tubo ca. 2,5 mm compr., limbo 1-1,4 mm compr.; flores do disco monoclinas, alvas, 3,7-4,2 mm compr., fauce infundibuliforme, glanduloso-pontuada, lobos ca. 0,6 mm compr., glabros, glandulosopontuados. Cipselas oblongas a oblanceoladas, 6,3-7,4 × 1,4-1,7 mm, setosas, ápice com apêndice colunar central; pápus 2-5 aristados, aristas eretas, $1-4 \mathrm{~mm}$ compr. 
Material examinado: GOIÁS: Posse, I.1965, fl. e fr., Belém \& Mendes 98 (UB). TOCANTINS: Arraias, II.2006, fl. e fr., Bringel \& Barbosa 310 (CEN, UB).

Pantropical. Ambientes perturbados. Flores e frutos em janeiro e fevereiro. Considerou-se Blainvilea rhomboidea Cass. sinônimo de B. acmella.

16. Calea abbreviata Pruski \& Urbatsch, Brittonia 40: 348. $1988 . \quad$ Fig. 3o

Ervas cespitosas, 19-26 cm alt., hirsutas a glabrescentes. Folhas opostas, inteiras, estreitas, elípticas a lanceoladas, 9-35 ×2-3 mm, glabras a glabrescentes, raramente hirsutas, sésseis, ápice agudo a obtuso, base cuneada a truncada, margem inteira, revoluta. Capítulos radiados, solitários, 7-11 mm diâm., pedúnculo 13-21 cm compr.; invólucro campanulado a hemisférico, 2-seriado; brácteas involucrais escariosas, desiguais, as internas maiores que as externas, ovais a lanceoladas, ciliadas, ápice obtuso; receptáculo plano, convexo; páleas planas, linear-lanceoladas, ápice agudo, face dorsal glabra. Flores do raio pistiladas, amarelas, glabras, tubo 1-1,5 mm compr., limbo 9-11 mm compr., glanduloso-pontuado na face abaxial; flores do disco monoclinas, amarelas, 4,7-6,3mm compr., fauce infundibuliforme, glabra, lobos 1,2-1,8 mm compr., glabros. Cipselas obpiramidais, 4,3-4,7×1,4-1,6 mm, glabras; pápus de escamas iguais, linearlanceoladas, 1-2 mm compr.

Material selecionado: GOIÁS: Alto Paraíso de Goiás, XI.2004, fl. e fr., Pastore \& Suganuma 1071 (CEN).

Brasil: GO, Chapada dos Veadeiros. Campo limpo. Flores e frutos de outubro a novembro.

17. Calea candolleana (Gardner) Baker in Martius \& Eichler, Fl. bras. 6(3): 256. 1884.

Fig. 3h, $\mathrm{p}$

Subarbustos ca. $50 \mathrm{~cm}$ alt., tomentosos a estrigosos. Folhas opostas, inteiras, elípticas, ovais ou lanceoladas, 33-67 × 7-25 mm, estrigosas a hirsutas, glanduloso-pontuadas na face abaxial, subsésseis, ápice obtuso, base obtusa a cuneada, margem serreada. Capítulos radiados, em dicásios, 8-15 mm diâm., pedúnculo 1-13 cm compr.; invólucro hemisférico a campanulado, 2-3-seriado; brácteas involucrais escariosas, desiguais, as internas maiores que as externas, ovais a lanceoladas, glabrescentes a estrigosas, ápice obtuso a mucronado; receptáculo plano, paleáceo; páleas planas, oblongo-lanceoladas, face adaxial glabra. Flores do raio pistiladas, amarelas, tubo ca. 3,4 mm compr., glabro ou tricomas esparsos, glanduloso-pontuado, limbo 7-11 mm compr., glabro, glanduloso-pontuado na face abaxial; flores do disco monoclinas, amarelas, 5-7 mm compr., fauce estreito-infundibuliforme, ocasionalmente glanduloso-pontuada, lobos 0,8$1 \mathrm{~mm}$ compr., glabros. Cipselas subcilíndricas a prismáticas, 5-5,5 × 1,2-1,4 mm, glabra, às vezes tuberculadas; pápus de escamas iguais, ovais a arredondadas, 0,3-0,5 mm compr.

Material selecionado: GOIÁS: Divinópolis de Goiás, V.2000, fl. e fr., Hatschbach et al. 71001 (MBM). TOCANTINS: Paranã, III.2004, fl. e fr., Sevilha et al. 3726 (CEN).

Brasil: MG GO, TO, PE (Baker 1884) e BA. Cerrado s.s. Flores e frutos de março a maio.

18. Calea cf. dalyi Pruski \& Ubatsch, Brittonia 39(2): 201.1987. Fig. 4d

Ervas 35-80 cm alt., eretas, hirsutas a vilosas. Folhas opostas, inteiras, elípticas a oblongas, 32-95 × 6-21 mm, hirsutas, glanduloso-pontuadas na face abaxial, sésseis, ápice obtuso a mucronulado, base cuneada a atenuada, margem serreada a crenada. Capítulos discóides, em dicásios umbeliformes, 3-5 mm diâm., pedúnculo 2-10 mm compr.; invólucro campanulado, 3-seriado; brácteas involucrais escariosas, desiguais, as internas maiores que as externas, ovais, lanceoladas ou oblongas, ápice acuminado a cuspidado, ciliadas; receptáculo plano, paleáceo; páleas côncavas, oblongas, ápice agudo, face dorsal glabra. Flores monoclinas, atropurpúreas a vináceas, 3-4 mm compr., fauce campanulada a infundibuliforme, glabra, lobos $0,8-1,4 \mathrm{~mm}$ compr., glabros. Cipselas prismáticas 3-3,2× ca. $1 \mathrm{~mm}$, glabras; pápus de escamas iguais, ovais, ca. 0,2 mm compr. 

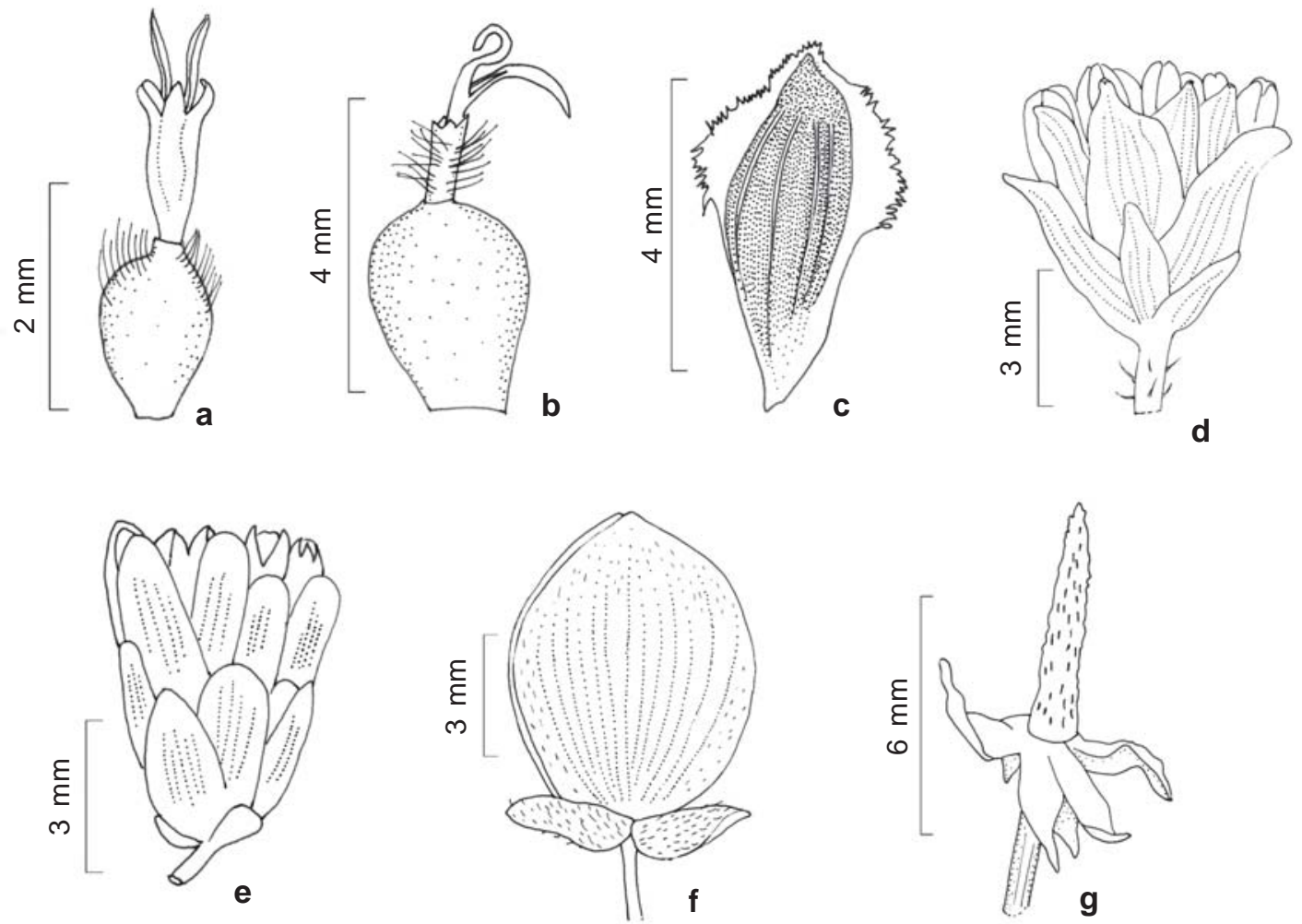

Figura 4 - Heliantheae na bacia do Rio Paranã (GO, TO). Flores externas (a-b), pálea do receptáculo (c), invólucro dos capítulos (d-f) e receptáculo do capítulo (g). a. Clibadium armanii; b. Ichthyothere integrifólia; c. Ichthyothere terminalis; d. Calea dalyi; e. Calea sp.1; f. Staurochlamys burchellii; g. Acmella uliginosa.

Figure 4 - Heliantheae in Paranã river basin (GO, TO). Outer flowers (a-b), receptacle palea (c), capitulum involucres (d-f) capitulum receptacle (g). a. Clibadium armanii; b. Ichthyothere integrifólia; c. Ichthyothere terminalis; d. Calea dalyi; e. Calea sp.1; f. Staurochlamys burchellii; g. Acmella uliginosa.

Material selecionado: TOCANTINS: Paranã, IV.2004, fl. e fr., Sevilha et al. 4125 (CEN).

Bolívia (Pruski \& Urbatsch 1987) e Brasil: TO. Mata estacional decidual, cerrado s.s. Flores e frutos de abril a maio. Os espécimes aqui analisados apresentam folhas de comprimento bem maior que os apresentados no material-tipo. No entanto, é possível que os espécimes coletados na bacia do rio Paranã representem um extremo de variação do comprimento da folha, já que o hábito, arquitetura, brácteas involucrais e características florais e do capítulo são muito semelhantes.

19. Calea elongata (Gardner) Baker in Martius \& Eichler, Fl. bras. 6(3): 255. 1884.

Subarbustos $0,4-1 \mathrm{~m}$ alt., glabros a pubérulos. Folhas opostas, inteiras, elípticas a lineares, $15-75 \times 1-20 \mathrm{~mm}$, glabras ou glabrescentes, glanduloso-pontuadas na face abaxial, sésseis a subssésseis, ápice obtuso, base atenuada, margem inteira, raramente serrilhada, revoluta. Capítulos radiados, em dicásios, 7-11 mm diâm., pedúnculo 1,67,2 cm compr.; invólucro campanulado, 3-4seriado; brácteas involucrais escariosas, desiguais, as internas maiores que as externas, ovais a oblongas, glabras ou pubérulas, curtociliadas, ápice agudo a obtuso; receptáculo plano, paleáceo; páleas planas, oblongas, ápice acuminado a cuspidado, face dorsal glabra. Flores do raio pistiladas, amarelas, glabras, tubo ca. 2-3,5 mm compr., limbo 6-10 mm compr., glanduloso-pontuado na face abaxial; flores do disco monoclinas, amarelas, 4,7-6 mm compr., fauce estreito-infundibuliforme a cilíndrica, glabra, lobos 0,8-1 mm compr. 
glabros. Cipselas prismáticas, 2,9-3 ×0,7$1 \mathrm{~mm}$; escamas iguais, oblongo-ovais, $0,2-$ $0,4 \mathrm{~mm}$ compr.

Material selecionado: GOIÁS: Teresina de Goiás, 02.1999, fl., Calago 102 (CEN). TOCANTINS: Paranã, IX.2004, fl. e fr., Sevilha et al. 3602 (CEN).

Brasil: GO, TO e BA. Campos úmido e rupestre. Flores e frutos de setembro a maio. Assemelha-se a C. gardneriana Baker, caracterizada pelas folhas lineares. Alguns espécimes de $C$. elongata apresentam folhas lineares, variando até mais largas. É necessária uma avaliação com relação à identidade destes dois táxons.

20. Calea fruticosa (Gardner) Urbatsch, Zoltsky \& Pruski, Syst. Bot. 11(4): 506. 1986.

Fig. 2i

Arbustos ca. 1,5 m alt., muito ramificados, pubescentes. Folhas opostas, inteiras, ovais a orbiculares 3,2-5,9 × 1,6-4,5 cm, glabras na face adaxial, estrigulosas e glandulosopontuadas na face abaxial, pecíolo $2-7 \mathrm{~mm}$ compr., ápice agudo a obtuso, mucronulado, base cuneada, obtusa ou truncada, margem denticulada a denteada. Capítulos discóides, em densos tirsóides corimbiformes, 2-4 mm diâm., sésseis ou pedúnculo até $6 \mathrm{~mm}$ compr.; invólucro cilíndrico, 5-7-seriado; brácteas involucrais escariosas, desiguais, as internas maiores que as externas, oblongas, as externas ovais, glabras a híspidas, ápice agudo a obtuso, ciliadas a viloso-ciliadas, raramente glandulosopontuadas; receptáculo plano, epaleáceo. Flores monoclinas, amarelas, 5,3-9 mm compr., fauce campanulada ou inconspícua, glabra, lobos 2,3-3 mm compr., glabros. Cipselas oblanceoladas a prismática, 5-6,6×1-1,2 mm, seríceas, glanduloso-pontuadas; escamas, subiguais, lanceoladas, 1,7-3 mm compr.

Material selecionado: GOIÁs: Alto Paraíso de Goiás, XI.2007, fr., Bringel et al. 397 (CEN).

Brasil: MG, GO e BA (Urbastch et al. 1986). Cerrado s.s. Flores em maio e frutos em novembro.
21. Calea hypericifolia (Gardner) Baker in Martius \& Eichler, Fl. bras. 6(3): 258. 1884.

Fig. 2l; 3r

Subarbustos 20-35 cm alt., estrigosos. Folhas opostas, inteiras, ovais a lanceoladas, 8-22×3-9 mm, estrigosas, glanduloso-pontuadas, sésseis ou pecíolo até $1 \mathrm{~mm}$ compr., ápice obtuso a agudo, base obtusa, raramente cuneada, margem inteira a serrilhada. Capítulos radiados em dicásios, 6-8 mm diâm.; pedúnculo 5-14 mm compr.; invólucro campanulado, 4-seriado; brácteas involucrais desiguais, as externas foliáceas, ovais, estrigosas, ápice obtuso, as internas escariosas, progressivamente maiores, ovais a oblongas, glabras, ápice agudo a obtuso; receptáculo convexo, paleáceo; páleas planas, oblongo-lineares, ápice agudo a acuminado, face dorsal glabra. Flores do raio pistiladas, amarelas, glabras, tubo ca. $2 \mathrm{~mm}$ compr., limbo 5,5-6,5 mm compr., glanduloso-pontuado na face abaxial; flores do disco monoclinas, amarelas, 4-5 mm compr., fauce campanulada, glabra, lobos 2,2-2,4 mm compr., glabros. Cipselas prismáticas, 3,2-3,8 × 0,7-0,8 mm, glabras; escamas iguais, ovais, ca. 0,3 mm compr. Material selecionado: GOIÁS: Vila Boa, III.2003, fl. e fr., Mendonça et al. 5364 (IBGE, UB). TOCANTINS: Paranã, III.2004, fl. e fr., Sevilha et al. 3775 (CEN).

Brasil: MG GO e TO (Baker 1884; Pruski \& Urbatsch 1987). Cerrado s.s. Flores e frutos em março.

22. Calea polycephala (Baker) H. Rob., Phytologia 32(5): 428. 1975.

Arbustos 1-1,5 m alt., pubérulos a estrigoso-pubescentes. Folhas opostas, inteiras, ovais ou raramente lanceoladas, 2,5-9 × 1,1$3,3 \mathrm{~cm}$, glabrescentes a estrigoso-pubescentes, pontuações glandulares às vezes inconspícuas, pecíolo 3-11 mm compr., ápice agudo a acuminado, base obtusa a atenuada, margem serreada ou crenada. Capítulos discóides, em tirsóides, 35 mm diâm., pedúnculo 3-16 mm compr.; invólucro cilíndrico a estreito-campanulado, 34-seriado; brácteas involucrais escariosas, desiguais, as internas progressivamente 
maiores, ovais a oblongas, glabras, às vezes ciliadas, ápice obtuso; receptáculo convexo, epaleáceo. Flores monoclinas, amarelas, 4-4,5 mm compr., fauce campanulada a infundibuliforme, glabra, lobos 1,2-1,5 mm compr., glabros. Cipselas prismáticas, 3,4-4,2 × 0,8-1,2 mm, às vezes com tricomas robustos e esparsos; escamas iguais, ovais, $0,1-0,7 \mathrm{~mm}$ compr.

Material examinado: TOCANTINS: Conceição do Tocantins, V.2000, fl. e fr., Hatschbach et al. 70936 (MBM).

Brasil: GO, TO, PA. Mata de galeria e cerrado s.s. Flores e frutos de fevereiro a maio.

23. Calea quadrifolia Pruski \& Urbatsch, Brittonia 40(4): 341. 1988.

Subarbusto 0,3-1 m alt., híspidos a estrigosos. Folhas verticiladas, geralmente 4 por nó, inteiras, elípticas a ovais 15-56×7-23 $\mathrm{cm}$, sésseis, glabrescentes a estrigosas, glanduloso-pontuadas, ápice agudo, base cuneada, margem serreada. Capítulos radiados, em corimbos, 12-22 mm diâm., pedúnculo 1565 mm compr.; invólucro hemisférico, 4-seriado; brácteas involucrais desiguais, as mais externas foliáceas, ovais, estrigosas, ápice agudo, as internas escariosas, progressivamente maiores, ovais, glabras ou ciliadas, ápice obtuso; receptáculo convexo, paleáceo; páleas planas, oblongolanceoladas, ápice agudo, face dorsal glabra. Flores do raio pistiladas, amarelas, glabras, tubo ca. 1,3 mm compr., limbo ca. 1,1 cm compr., glanduloso-pontuado na face abaxial; flores do disco monoclinas, amarelas, 5-6 mm compr., fauce campanulada, glabra, lobos ca. $1 \mathrm{~mm}$ compr., glabros. Cipselas oblanceoladas, ca. $3,7 \times 1,3 \mathrm{~mm}$, glabras; escamas desiguais, oblongo-lanceoladas, 1,5-2,1 mm compr.

Material examinado: GOIÁS: Alto Paraíso de Goiás, III.1988, fl., Ginsbarg \& César 751 (UB).

Brasil: GO e DF (Pruski \& Urbatsch 1988). Em campos arenosos e rupestres. Flores em março.

24. Calea ramosissima Baker in Martius \& Eichler, Fl. bras. 6(3): 257. 1884 Fig. 2j

Subarbustos ca. $50 \mathrm{~cm}$ alt., muito ramificados, glabrescentes a esparso- pubescentes. Folhas opostas, inteiras, lineares, 16-42 ×0,5-2 mm, glabras na face adaxial e setulosa na face abaxial, sésseis, ápice agudo a obtuso, base atenuada, margem inteira a serreada. Capítulos radiados, em dicásios densos, 5-9 mm diâm., pedúnculo 1-3 cm compr.; invólucro campanulado, 4-seriado; brácteas involucrais desiguais, as externas foliáceas, linear-lanceoladas, glabras, ápice agudo, as internas escariosas, gradativamente maiores, ovais a lanceoladas, glabras, ápice agudo a obtuso; receptáculo convexo, paleáceo; páleas côncavas, elípticas, ápice agudo, face dorsal glabra. Flores do raio pistiladas, amarelas, glabras, tubo ca. 2,2 mm compr., limbo ca. 7,5 mm compr., glandulosopontuado na face abaxial; flores do disco monoclinas, amarelas, 5,5-5,9 mm compr., fauce amplo-cilíndrica a campanulada, glabra, lobos ca. 2,5 mm compr., glabros. Cipselas prismáticas, 4-4,5 × 0,6-0,9 mm, glabras, às vezes tuberculadas; uma escama oval maior, 1-1,4 mm compr., as demais oblongo-ovais, $0,5-0,7 \mathrm{~mm}$ compr.

Material examinado: GOIÁS: São Domingos, V.2000, fl. e fr., Hatschbach et al. 71155 (MBM).

Brasil: GO, MG (Baker 1884; Nakajima \& Semir 2001). Ambientes rupestres. Flores e frutos em maio.

25. Calea sickii (G M. Barroso) Urbatsch, Zlotsky \& Pruski, Syst. Bot. 11(4): 504. 1986.

Fig. 2k

Arbustos ca. 1,3 m alt., glabrescentes. Folhas alternas ou opostas, inteiras, ovais, 3,4$7,5 \times 2,2-7,4 \mathrm{~cm}$, glabras, sésseis, ápice agudo a obtuso, mucronado, base obtusa a cordada, margem serreada a denteada. Capítulos discóides, em tirsóides corimbiformes, 8-10 mm diâm., pedúnculo 5-15 mm compr.; invólucro cilíndrico a turbinado, 5-6-seriado; brácteas involucrais escariosas, desiguais, as internas maiores que as externas, ovais a oblongas, glabras, ápice obtuso; receptáculo convexo, paleáceo; páleas planas, oblongas, ápice obtuso, face dorsal glabra. Flores monoclinas, amarelas, ca. 7,5 mm compr., fauce campanulada, glabra, glanduloso-pontuada, lobos ca. 2 mm compr., 
glabros. Cipselas prismáticas, ca. $5 \times 2 \mathrm{~mm}$ compr., seríceas; escamas 4-5 mm compr., unidas até mais da metade.

Material examinado: GOIÁS: Alto Paraíso de Goiás, III.1971, fl., Irwin et al. 32903 (UB).

Brasil: GO, DF. Ambientes rupestres. Flores e frutos de janeiro a maio (Urbatsch et al. 1986).

26. Grupo de Calea teucriifolia (Gardner) Baker sensu Pruski \& Urbatsch (1987).

Subarbustos ou arbustos, 40-80 cm alt., estrigosos, hirsutos, vilosos ou incano-velutinos. Folhas opostas, inteiras, ovais a oblongoelípticas, 8-38 × 3-20 mm, pubescentes a tomentosas, glanduloso-pontuadas, sésseis, ápice agudo a obtuso, base atenuada, margem serreada. Capítulos radiados, em cimeiras, 1,11,3 cm diâm., pedúnculo 1,4-3 cm compr.; invólucro campanulado a hemisférico, 3-4seriado; brácteas involucrais desiguais, as externas foliáceas, ovais pubescentes a tomentosas, ápice agudo a obtuso, as internas escariosas, progressivamente maiores, ovais, glabras ou ciliadas, ápice obtuso; receptáculo convexo, paleáceo; páleas conduplicadas, oblongas, ápice cuspidado, face dorsal glabra. Flores do raio pistiladas, amarelas, glabras, tubo ca. 2,5 mm compr., limbo 8,2-11 mm compr., glanduloso-pontuado na face abaxial; flores do disco monoclinas, amarelas, 5,2-7 mm compr., fauce campanulada a cilíndrica, glabra, lobos 1,8-3,2 mm compr., glabros. Cipselas prismáticas, 3,8-5,5 × 1-1,4 mm, glabras a setosas; escamas iguais, oblongo-ovais, 0,5$1 \mathrm{~mm}$ compr.

Material selecionado: GOIÁS: Posse, III.2001, fl. e fr., Fonseca et al. 2500 (CEN, IBGE).

Brasil: MG, GO, DF, BA, PE (Baker 1884; Pruski \& Urbatsch 1987). Campo limpo/mata de galeria, cerrado s.s., cerrado rupestre. Flores e frutos de fevereiro a maio. Segundo Pruski \& Urbatsch (1987), o grupo de $C$. teucriifolia reúne táxons com limites pouco definidos. Nele, estão as espécies Calea ferruginea Sch.-Bip. ex Baker, C. microphylla (Gardner) Baker, C. teucriifolia (Gardner) Baker e C. villosa Sch.-Bip. ex Baker.
Baker (1884) diferenciou estas espécies de forma pouco clara, basicamente com base no tamanho e formato das folhas e tipo de indumento. Sendo assim, dentro deste grupo de espécies o indumento pode variar desde pubérulo ou pubescente (em C. microphylla, C. teucriifolia e C. ferruginea) até albotomentoso (em C. villosa); o comprimento das folhas de (4-6 mm em C. microphylla, 8-12 $\mathrm{mm}$ em C. villosa e C. ferruginea, e 1,8-3 $\mathrm{cm}$ em $C$. ferruginea) e a base das folhas (cuneada ou atenuada em $C$. ferruginea, C.microphylla e C. teucriifolia, até rotunda ou cordada em C. villosa). Na Bacia do Paranã, os espécimes parecem se enquadrar melhor dentro das circuscrições de $C$. ferruginea e C. villosa.

\section{Calea sp. 1}

Fig. 3q; 4e

Subarbustos ou arbustos 0,6-1 m alt., glabros a hirtelos. Folhas opostas, inteiras, elípticas a oblongas, 15-34 × 4-8 mm, hispídulas, glanduloso-pontuadas na face abaxial, sésseis, ápice agudo, base cuneada a atenuada, margem serrilhada a crenulada. Capítulos discóides, em dicásios, 4-6 mm diâm., pedúnculo (2)14-24 mm compr.; invólucro estreito-campanulado, 4-seriado; brácteas involucrais escariosas, desiguais, as internas maiores que as externas, ovais a oblongas, ciliadas, ápice obtuso; receptáculo convexo, apenas 1 pálea, plana, lanceolada, ápice agudo, face dorsal glabra. Flores monoclinas, amarelas, 4-5,2 mm compr., fauce campanulada, glabra, lobos 1,1-1,5 mm compr., glabros. Cipselas prismáticas, 3,6-4×0,8-1 mm, glabras; páleas iguais, oval-oblongas, 0,2-0,3 mm compr.

Material examinado: GOIÁS: Cavalcante, IV.2004, fl. e fr., Fonseca et al. 5033 (IBGE).

Brasil: GO. Cerrado rupestre. Assemelhase à Calea polycephala. No entanto, Calea sp.1 apresenta folhas mais estreitas, com até $8 \mathrm{~mm}$ de largura, oblongas a elípticas e capítulos com uma única pálea no receptáculo, enquanto $C$. polycephala apresenta folhas mais largas, com mais de $1 \mathrm{~cm}$ de largura, ovais e capítulos sem pálea no receptáculo. 
28. Chrysanthellum indicum DC. var. afroamericanum B. L.Turner, Phytologia. 51: 291. 1982.

Fig. 2g-h

Ervas até $30 \mathrm{~cm}$ alt., eretas ou procumbentes, glabras. Folhas rosuladas basais ou alternas, 2-3-pinatisectas, $1-3 \times 1,2-3,5 \mathrm{~cm}$, glabras, pecíolo $1-4 \mathrm{~cm}$ compr., pinas com base cuneada, segmentos oblongos, ca. $1 \mathrm{~mm}$ larg., ápice mucronado, margem inteira. Capítulos radiados, em cimeiras assimétricas, 5-8 mm diâm., pedúnculo 1,5-3,5 cm compr.; invólucro hemisférico, 3-seriado; brácteas involucrais escariosas, desiguais, as externas inconspícuas, as demais maiores, ovais ou oblongo-ovais, glabras, ápice agudo a obtuso; receptáculo plano, paleáceo; páleas planas, oblongas, ápice obtuso, face dorsal glabra. Flores do raio pistiladas, amarelas, glabras, tubo ca. 0,5 mm compr., limbo ca. 2,3 mm compr.; flores do disco monoclinas, amarelas, 1,5-2 mm compr., fauce cilíndrica, glabra, lobos ca. 0,3 mm compr., glabros. Cipselas do raio claviformes, 2,8-3 $\times$ ca. $1 \mathrm{~mm}$, glabras ou tricomas esparsos; cipselas do disco oblongo-obovais, 2,6-2,8 × ca. $1 \mathrm{~mm}$, aladas, alas ca. 0,1 mm larg., ciliadas; pápus ausente.

Material selecionado: GOIÁS: Vila Boa, III.2003, fl. e fr., Mendonça et al. 5363 (IBGE, UB). TOCANTINS: Combinado, II.2006, fl. e fr., Bringel \& Barbosa 290-B (CEN, UB).

América do Sul e África (Turner 1988). Cerrado s.s e ruderal. Flores e frutos de fevereiro a março.

29. Clibadium armanii (Balb.) Sch. Bip. ex O. E. Schulz, Linnaea 30: 180. 1859. Fig. 4 a

Subarbustos ou arbustos 0,5-1,5 m alt., estrigulosos a hispidulosos. Folhas opostas, inteiras, ovais, 2,7-7,4 × 1,3-4,5 cm, estrigulosas a estrigosas, pecíolo $3-9 \mathrm{~mm}$ compr., ápice mucronulado, base obtusa, margem serreada. Capítulos disciformes, em tirsóides corimbiformes, densos, 4-5 mm diâm., sésseis ou pedúnculo até $7 \mathrm{~mm}$ compr.; invólucro campanulado a subgloboso, 2-seriado; brácteas involucrais escariosas, subiguais, ovais, estrigulosas na metade superior, ápice agudo; receptáculo plano, epaleáceo. Flores externas pistiladas, 3 por capítulo, alvas, glabras, ca. 1,8 mm compr.; flores internas estaminadas, alvas, ca. 3,2 mm compr., fauce cilíndrico-campanulada, lobos ca. 0,6 mm compr., setosos. Cipselas subglobosas, 3,1-3,5 $\times 3,1-3,2 \mathrm{~mm}$, setosas a tomentosas no ápice; pápus ausente.

Material selecionado: GOIÁS: Formosa, III.2003, fl. e fr., Fonseca et al. 4376 (IBGE, UB).

Paraguai e Brasil: PR, SP, RJ, MG, BA, GO, DF e MG (Arriagada 2003). Mata de galeria e cerrado s.s. Flores e frutos entre março e maio.

30. Cosmos caudatus Kunth, Nov. gen. sp. 4: 240.1820.

Fig. 2f; 3b

Ervas até 2,5 m alt., com tricomas secretores multisseptados. Folhas opostas, 23-pinatipartidas, 5-13,5 ×3,6-14,4 cm, glabras, segmentos elípticos, lanceolados, oblongolineares, ápice acuminado a cuspidado, base cuneada, margem inteira, estrigoso-ciliada; pecíolo 5-50 mm compr. Capítulos radiados, em dicásios, 1-2,3 cm diâm., pedúnculo 8-17,5 cm compr.; invólucro campanulado, 2-seriado; brácteas involucrais escariosas, desiguais, as externas estreito-lanceoladas, ciliadas, ápice acuminado a caudado, as internas mais largas, oblongo-lanceoladas, glabras, ápice agudo a acuminado; receptáculo plano, paleáceo; páleas oblongas, ápice agudo, face dorsal glabra. Flores do raio neutras, róseas, tubo ca. 1,3 mm compr., glabro, limbo ca. $7 \mathrm{~mm}$ compr., pubérulo na face abaxial; flores do disco monoclinas, amarelas, 6,8-8 mm compr., fauce infundibuliforme, glabra, lobos 1,2-1,5 mm compr, ciliados. Cipselas fusiformes, ca. $7 \times$ $1,2-1,5 \mathrm{~mm}$, rostro apical 5-19 mm compr., estriguloso; pápus 2-3-aristado, aristas inclinadas a reflexas, 3-4 mm compr.

Material selecionado: GOIÁS: Monte Alegre, IV.2000, fl. e fr., Aparecida-Silva et al. 4370 (CEN, IBGE).TOCANTINS: Arraias, II.2006, fl. e fr., Bringel \& Barbosa 289 (CEN, UB).

EUA (Flórida), América Central, Brasil, Paraguai. Introduzida na Ásia (Sherff 1932). Ambientes perturbados. Flores e frutos de fevereiro a abril. 
31. Dimerostemma bishopii H. Rob., Phytologia 49: 275. 1981.

Fig. 2c

Arbustos 1,2-2 m alt., hirtelos. Folhas opostas, inteiras, ovais, 3,7-13 × 2,7-6 cm, pecíolo $6-11 \mathrm{~mm}$., estrigosas a tomentosas, glanduloso-pontuada. ápice agudo a cuspidado, base atenuada, truncada ou cordada, margem serreada. Capítulos radiados, solitários ou em dicásio, 1,4-2,2 cm diâm., pedúnculo 5-15 cm compr.; invólucro de brácteas patentes, 2seriado; brácteas involucrais foliáceas, desiguais, as extenas muito maiores que as internas, estrigosas a tomentosas, glandulosopontuadas, ápice obtuso-mucronado; receptáculo convexo, paleáceo; páleas conduplicadas, oblanceoladas, ápice agudo a acuminado, franjado, face dorsal glabrescente. Flores do raio neutras, amarelas, setosas, tubo 1-1,4 mm compr., limbo 1,2-2 cm compr.; flores do disco monoclinas, amarelas, 4,4-5,7 mm compr., fauce cilíndrica, ocasionalmente setosas, glanduloso-pontuados, lobos ca. 0,5 $\mathrm{mm}$ compr., setosos. Cipselas obovais, ca. $4 \times$ $1,5 \mathrm{~mm}$, glabras, lisas ou tuberculadas, alas ausentes; pápus inconspícuo, aristas eretas, até 0,4 mm compr., escamas inconspícuas.

Material selecionado: GOIÁS: Nova Roma, III.2000, fl. e fr., Aparecida-Silva et al. 4309 (CEN, IBGE).

Brasil: GO. Cerrado s.s./mata decídua. Flores de fevereiro a março (Moraes \& Semir, dados não publicados).

32. Dimerostemma goyazense (Gardner) M. D. Moraes, Phytologia 89: 117. 2007.

Fig. $2 \mathrm{~m}$

Arbustos ca. 1,5-2 m alt., estrigulosos a tomentosos. Folhas opostas, inteiras, ovais a deltóides, 7,7-13,5 ×3,4-9,5 cm, estrigosas a vilosas, glanduloso-pontuadas na face abaxial, pecíolo 11-24mm, ápice acuminado a cuspidado, base atenuada, raramente truncada, margem serreada, estrigosas. Capítulos radiados, em dicásios, 1-1,8 mm diâm., sésseis ou pedúnculo até $57 \mathrm{~mm}$ compr.; invólucro de brácteas patentes, 2-seriado; brácteas involucrais foliáceas, desiguais, as externas bem maiores que as internas, oblongas a oblanceoladas, estrigosas a tomentosas, glanduloso-pontuadas, ápice obtusomucronado a agudo; receptáculo convexo, paleáceo; páleas conduplicadas, oblanceoladas, ápice acuminado a caudado, ciliado, face dorsal de nervura central curtamente ciliada. Flores do raio pistiladas, amarelas, setosas, tubo ca. $1 \mathrm{~mm}$ compr., limbo 1,3-2,3 cm compr.; flores do disco monoclinas, 5-6,6 mm compr., fauce cilíndrica, geralmente setosa, lobos $0,5-0,9 \mathrm{~mm}$ compr., setosos, glanduloso-pontuados. Cipselas do raio obovais, ca. 3,5 ×1,5 mm, glabras, tuberculadas, alas ausentes; cipselas do disco oblanceoladas, 3,2-4×1,3-1,6 mm, glabras, lisas a tuberculadas, alas até $1 \mathrm{~mm}$ larg.; pápus ausente nas do raio; nas do disco, aristas eretas $0,4-0,7 \mathrm{~mm}$ compr., escamas 0,4-0,7 mm compr.

Material selecionado: GOIÁS: Guarani de Goiás, III.2001, fl. e fr.,Aparecida-Silva et al. 4847(CEN, IBGE). TOCANTINS: Aurora do Tocantins, V.2000, fl. e fr., Hatschbach et al. 70825(MBM).

Brasil: MG GO, DF e TO. Matas deciduais. Flores e frutos de fevereiro a abril (Moraes \& Semir, dados não publicados).

33. Dimerostemma grazielae H. Rob., Proc. Biol. Soc. Wash. 97(3): 623. 1984.

Arbustos 1-1,5 m alt., estrigosos a tomentosos. Folhas opostas, inteiras, ovais a elípticas, 26-86 × 9-36 mm, estrigosas a tomentosas, pecíolo até $4 \mathrm{~mm}$ compr., ápice agudo, base atenuada, margem serrilhada a serreada. Capítulos radiados, em dicásios, 1,32,1 cm diâm., pedúnculo 2-6 cm compr.; invólucro de brácteas patentes, 2-seriado; brácteas involucrais foliáceas, desiguais, as externas bem maiores que as internas, lineares a estreito-oblanceoladas, estrigosas a vilosas, ápice agudo; receptáculo convexo, paleáceo; páleas conduplicadas, oblongas, ápice obtusomucronado, ocasionalmente ciliado, face dorsal glabrescente. Flores do raio neutras, amarelas, glabras, tubo ca. $1 \mathrm{~mm}$ compr., limbo 6-8 mm compr.; flores do disco monoclinas, amarelas, 4,8-5,7 mm compr., fauce cilíndrica, glabra, lobos $0,5-0,8 \mathrm{~mm}$ compr., setosos. Cipselas oblanceoladas, 4,1-5 × 1,4-1,6 mm, glabras, lisas a tuberculadas, alas $0,3-0,7 \mathrm{~mm}$ larg.; 
pápus 2-3-aristado, aristas eretas, até 0,4 mm compr., escamas inconspícuas.

Material selecionado: GOIÁS: Alto Paraíso de Goiás, V.1994, fl. e fr., Bridgewater et al. 196 (UB).

Brasil: Chapada dos Veadeiros. (Moraes \& Semir, dados não publicados) Campo e cerrado rupestre. Flores de fevereiro a maio.

34. Dimerostemma vestitum (Baker) S. F. Blake, Contr. Gray. Herb. 52: 11. 1917.

Fig. 2d

Subarbustos 0,5-1 m alt., cespitosos, hirsutos a vilosos. Folhas opostas, inteiras, ovais 1,7-5,5 × 1,6-5,6 cm, seríceas a tomentosas, pecíolo 2-7 mm compr., ápice agudo a obtuso, base obtusa a cordada, margem crenada a serreada. Capítulos solitáros ou em antelódios laxos; 1,5-2,5 cm diâm., pedúnculo 5-40 mm compr.; invólucro de brácteas patentes, 2seriado; brácteas involucrais foliáceas, desiguais, as externas bem maiores que as internas, ovais a obovais, tomentosas, glanduloso-pontuadas, ápice agudo a obtuso; receptáculo convexo, paleáceo; páleas conduplicadas, oblongas, ápice acuminado, face dorsal glabrescente. Flores do raio neutras, amarelas, tubo ca. $2 \mathrm{~mm}$ compr., hirsuto, limbo 1,2-2,2 cm compr., setoso na face abaxial; flores do disco monoclinas, amarelas, 5,7-7 mm compr., fauce cilíndrica, ocasionalmente setosa, lobos ca. 1 mm compr., ocasionalmente setosos, glanduloso-pontuados. Cipselas obovais 3,2-4,1 1 1,5-1,6 mm, glabras, lisas, alas inconspícuas até $0,1 \mathrm{~mm}$ larg.; pápus 2-aristado, aristas eretas, 1-2 mm compr., escamas inconspicuas ou até 0,3 mm compr.

Material examinado: GOIÁS: Formosa, IV.1966, fl. e fr., Irwin et al. 15141 (MBM).

Brasil: GO, MG, DF. Campo e cerrado s.s. Flores e frutos de dezembro a abril (Moraes \& Semir, dados não publicados).

35. Ichthyothere connata S. F. Blake, J. Wash. Acad. Sci. 16: 419. 1926.

Ervas a subarbustos 40-60 cm alt., eretos, glabros, pruinosos. Folhas opostas, inteiras, ovais 26-80 × 13-36 mm, glabras, sésseis, ápice agudo, às vezes mucronado, base obtusa, às vezes amplexicaule, margem inteira a sinuosa. Capítulos disciformes, em glomérulos ou dicásios, 8-14 mm diâm., sésseis ou pedúnculo até 1,6 cm compr.; invólucro globoso, 2-seriado; brácteas involucrais escariosas, desiguais, as externas reduzidas, obovais, glabras, ápice obtuso, as internas bruscamente maiores, orbiculares, côncavas, glabras, ápice obtuso; receptáculo cônico, paleáceo; páleas côncavas, obovais ou obtruladas, margem hialina, lacerada, ápice agudo a obtuso, face dorsal glabra, pruinosa. Flores externas, pistiladas, 2 por capítulo, alvas ca. 1,5 mm compr., denso-hirsutas; flores internas estaminadas, alvas, 4,7-5,7 mm compr., fauce indistinta, glabra, lobos $0,5-0,7 \mathrm{~mm}$ compr., glanduloso-pontuados. Cipselas obovóides, 5,76,5 × 4,5-5,5 mm, glabras; pápus ausente.

Material selecionado: GOIÁS: Alto Paraíso de Goiás, fl. e fr., II.2004, Bringel et al. 93 (CEN).

Brasil: Goiás, Chapada dos Veadeiros. Campos rupestre e cerrado. Flores e frutos de dezembro a março (Pereira 2001).

36. Ichthyothere integrifolia (DC.) Baker in Martius \& Eichler, Fl. bras. 6(3): 157. 1884.

Fig. 4b

Ervas $20-40 \mathrm{~cm}$ alt., cespitosas, hirsutas. Folhas opostas, inteiras, elípticas, $12-55 \times 5-$ 29 mm, híspidas a hirsuto-vilosas, glandulosopontuadas, sésseis, ápice agudo a acuminado, base cuneada, raramente obtusa, margem inteira a serreada. Capítulos disciformes, em glomérulos densos ou cimeiras, 6-7 mm diâm., sésseis ou pedúnculo até $6 \mathrm{~mm}$ compr.; invólucro globoso, 2-seriado; brácteas involucrais escariosas, desiguais, as externas reduzidas, deltóides, estrigosas, ápice obtuso; as internas bruscamente maiores, orbiculares, côncavas, hispídulosas, ápice obtuso; receptáculo colunar, paleáceo; páleas côncavas, obovais a oblanceoladas, margem hialina, lacerada, ápice agudo, face dorsal ocasionalmente híspida. Flores externas, pistiladas, 3-4 por capítulo, alvas, 1,5-1,7 mm compr., denso-hirsutas; flores internas estaminadas, alvas, ca. $4 \mathrm{~mm}$ compr., fauce indistinta, glabra, lobos ca. 0,5 mm compr., 
glanduloso-pontuados. Cipselas obovóides 4,35,6×3-3,8 mm, glabrescentes pápus ausente. Material examinado: GOIÁS: Flores de Goiás, X.1997, fl. e fr., Aparecida-Silva et al. 3394 (IBGE).

Paraguai e Brasil: PR, SP, MG, GO, DF, MG e TO. Cerrado, campo úmido e rupestre (Pereira 2001). Flores e frutos durante início do período chuvosos.

37. Ichthyothere mollis Baker in Martius \& Eichler, Fl. bras. 6(3): 156. 1884.

Subarbustos até $40 \mathrm{~cm}$ alt., eretos ou prostrados, hirsutos a híspidos. Folhas opostas, inteiras, ovais, oblongas, elípticas ou obovais 3,7-14 × 1,7-4,3 cm, estrigulosas a hirsutas, glanduloso-pontuadas na face abaxial, ápice agudo a cuspidado, base cuneada, obtusa ou truncada, margem inteira a serreada. Capítulos disciformes, em um ou mais glomérulos, 7-10 mm diâm., sésseis; invólucro subgloboso, 2seriado; brácteas involucrais escariosas, desiguais, as externas reduzidas, deltóides, estrigosas, ápice obtuso, as internas bruscamente maiores, orbiculares, côncavas, estrigosas, pruinosas, ápice obtuso; receptáculo cônico, paleáceo; páleas côncavas ou levemente curvadas, obovais a elípticas, margem hialina ciliada ou não hialina, inteira, ápice agudo, face dorsal glabra. Flores externas pistiladas, 2 por capítulo, alvas, 1-1,5 mm compr., denso-hirsutas; flores internas estaminadas, alvas, 4,2-5 mm compr., fauce indistinta ou infundibuliforme, glabra, lobos 0,5-0,7 mm compr., glandulosopontuados. Cipselas obovóides, ca. $6 \times 3,4 \mathrm{~mm}$, esparso-setosas; pápus ausente.

Material selecionado: GOIÁS: Vila Boa, III.2003, fl. e fr., Mendonça et al. 5395 (IBGE).

Brasil: PR, SP, MG GO, MG e RO (Pereira 2001). Em cerrado. Flores no mês de março.

38. Ichthyothere terminalis (Spreng.) S. F. Blake, J. Wash. Acad. Sci. 11: 301. 1921.

Fig. 4 c

Ervas a arbustos 0,6-2 m alt., esparsohirsutas ou tricomas somente na região nodal e na inflorescência. Folhas opostas, inteiras, lanceoladas a oblongo-lancedoladas, 39-130× 7-22 mm, glabras, raramente com tricomas esparsos, sésseis, ápice agudo a caudado, base cuneada a obtusa, margem inteira a serreada. Capítulos disciformes em glomérulos, 5-8 mm diâm., sésseis ou pedúnculo até 3 mm compr.; invólucro subgloboso, 2-seriado; brácteas involucrais escariosas, desiguais, as externas, reduzidas, ovais, glabras, ápice obtuso, as internas bruscamente maiores, orbiculares, côncavas, glabras, ápice obtuso; receptáculo cônico, paleáceo; páleas obovais a oblanceoladas, margem hialina, ciliada, ápice agudo, face dorsal ocasionalmente híspida. Flores externas pistiladas, 2 por capítulo, alvas, 0,6-1,5 mm compr., denso-hirsutas; flores internas estaminadas, alvas, 3-4,5 mm compr., fauce indistinta ou infundibuliforme, glabra, lobos ca. 0,6 mm compr., glanduloso-pontuados. Cipselas obovais, 4-4,5 ×3,1-4,2 mm, glabras pápus ausente.

Material selecionado: GOIÁS: Cavalcante, IV.2004, fl., Fonseca et al. 5127 (IBGE, UB).

Guianas e Brasil: AC, AP, AM, PI, CE, PB, PE, BA, TO GO, MT, MG, SP. Cerrado e cerrado rupestre. Flores e frutos de março a maio (Pereira 2001).

39. Melampodium paniculatum Gardner, London J. Bot. 7: 287. 1848. Fig. 2p; 3s

Ervas ca. $80 \mathrm{~cm}$ alt., pubescentes, tricomas glandulares capitados. Folhas opostas, inteiras, lanceoladas, 5,1-9,4 × 1-3,6 cm, estrigosas, subsésseis, ápice agudo a cuspidado, base atenuada, margem serreada a serrilhada. Capítulos em dicásios, 4-8 mm diâm., pedúnculo 9-33 mm compr.; invólucro hemisférico, 2seriado; brácteas involucrais foliáceas, desiguais as externas ovais a amplo-elípticas, setosas a seríceas, tricomas glandulares, ápice cuspidado, as internas fundidas por completo às paredes das cipselas; receptáculo plano, paleáceo; páleas côncavas, elípticas, ápice agudo, pubescente-ciliado, face dorsal glabra. Flores do raio pistiladas, amarelas, tubo inconspícuo, limbo 1,8-3,5 mm compr., setoso na face adaxial setosa; flores do disco estaminadas, amarelas, 3,8-4 mm compr., fauce cilíndrica a estreito-infundibuliforme, glabra, lobos 0,7-0,9 mm compr., setoso no ápice. Cipselas assimétricas, obovais, 3,1-3,5 × 1,9-2,5 mm, 
glabras a pubérulas, rugosas, 2 depressões longitudinais, curvadas; pápus ausente.

Material selecionado: GOIÁS: Posse, II.1981, fl. e fr., King \& Bishop 8800(UB). TOCANTINS: Arraias, II.2006, fl. e fr., Bringel \& Barbosa 288 (CEN, UB).

América Central, introduzida no Brasil (Stuessy 1972). Ambientes perturbados. Flores e frutos em fevereiro.

40. Riencourtia oblongifolia Gardner, London J. Bot. 7: 287. 1848.

Subarbustos cespitosos ca. $60 \mathrm{~cm}$ alt., glabrescentes a estrigosos. Folhas opostas, inteiras, elípticas, oblongas ou lanceoladas, 4375×4-18 mm, estrigosas, pecíolo 1-6 mm compr., ápice agudo a obtuso-mucronado, base cuneada, margem inteira a serrilhada. Capítulos disciformes, em dicásios de glomérulos, ca. 3 mm diâm., sésseis; invólucro oboval, 2-seriado; brácteas involucrais escariosas, subiguais, obovais, estrigosas no ápice, ápice obtusomucronado; receptáculo plano, epaleáceo. Flor externa pistilada, 1 por capítulo, alva, 2-2,7 mm compr.; flores estaminadas 2,2-2,5 mm compr., fauce indistinta, glabra, lobos ca. 0,6 mm compr., longo-setosos. Cipselas globosas, 4,5-5×3,1$3,3 \mathrm{~mm}$, setosas no ápice; pápus ausente.

Material selecionado: GOIÁS: Monte Alegre, II.2006, fl. e fr., Bringel \& Barbosa 295 (CEN, UB). TOCANTINS: Paranã, II.2006, fl. e fr., Bringel \& Barbosa 282 (CEN, UB).

Bolívia (Pruski 1998) e Brasil: SP, MG GO, DF, MT e TO. Cerrado s.s. Flores de fevereiro a março.

41. Riencourtia tenuifolia Gardner, London J. Bot. 7: 287. 1848.

Subarbustos cespitosos 70-90 cm alt., estrigulosos ou estrigosos. Folhas opostas, inteiras, lineares, $18-56 \times \mathrm{ca} .1 \mathrm{~mm}$, estrigulosas, sésseis, ápice agudo a obtuso, base truncada, margeminteira. Capítulos em dicásios deglomérulos, 2-2,5 mm diâm., sésseis; invólucro oboval, 2seriado; brácteas involucrais escariosas subiguais, oblongas a obovais, estrigosas no no ápice, ápice obtuso-mucronado; receptáculo plano, epaleáceo. Flor externa pistilada, 1 por capítulo, alva, ca. 3 mm compr.; flores internas estaminadas, 2,1-2,5 $\mathrm{mm}$ compr., fauce indistinta, glabra, lobos ca. 0,6 mm compr., longo-setosos. Cipselas globosas, 4,4-5×2,22,4 mm, setosas no ápice, pápus ausente.

Material selecionado: GOIÁS: Mambaí, II.2003, fl.e fr., Fonseca et al. 4144 (IBGE).

Brasil: GO, DF, TO e BA. Cerrado s.s. Flores e frutos de outubro a maio.

42. Spilanthes nervosa Chodat, Bull. Herb. Boissier, sér. 2, 3: 724. 1903.

Fig. 2x

Ervas 15-20 cm alt., hirsutas. Folhas opostas, inteiras, oblongas, elípticas ou lanceoladas, 15$25 \times 3-6$ mm, glabras, sésseis, ápice agudo a obtuso, base cuneada, margem inteira. Capítulos solitários ou aos pares, 1-1,4 cm diâm., pedúcunlo 11-17 cm compr.; invólucro hemisférico, 2-seriado; brácteas involucrais foliáceas, subiguais, ovais a oblongas, glabras, ápice agudo a obtuso; receptáculo cônico, paleáceo; páleas côncavas, obovais, ápice agudo a obtuso, face dorsal glabra. Flores monoclinas, alvas, 2,4-3,3 mm compr., fauce subglobosa, glabra, lobos ca. 0,7 mm compr., glabros. Cipselas obovais, 2,5-2,7 × 1,7-2,1 $\mathrm{mm}$, longo-ciliadas; pápus 2-aristado, aristas eretas, robustas ca. $1 \mathrm{~mm}$ compr.

Material examinado: GOIÁS: Alto Paraíso de Goiás, XI.1996, fl. e fr., Fonseca et al. 1302 (IBGE).

Colômbia, Venezuela, Bolívia, Paraguai, Brasil: Centro-Oeste e Sul (Jansen 1981). Campo limpo. Flores setembro a março.

43. Staurochlamys burchellii Baker, Hooker's Icon. Pl. 19: 1825. $1889 . \quad$ Fig. 3i; 4f

Ervas $30-45 \mathrm{~cm}$ alt., anuais, estrigulosas. Folhas opostas, inteiras, lanceoladas, 15-36 $\times$ 2-5 mm, estrigulosas, glanduloso-pontuadas, sésseis, ápice agudo a obtuso, base atenuada, margem inteira. Capítulos radiados, em dicásio, 6-9 mm diâm., pedúnculo 6-13 cm compr.; invólucro 3-seriado, achatado; brácteas involucrais desiguais, as externas foliáceas, ovais, menores que as intermediárias; as intermediárias foliáceas, maiores, orbiculares, estrigulosas, ápice obtuso, as internas escariosas, encobertas pelas intermediárias, 
oblongas ou naviculares, glabras a esparsosetosas, ápice agudo a obtuso; receptáculo plano, paleáceo; páleas, planas, lineares, ápice acuminado, glabras. Flores do raio pistiladas, amarelas, tubo ca. 2,8 mm compr., limbo 3partido, segmentos ca. 2,5 mm compr., glanduloso-pontuados na face abaxial; flores do disco monoclinas, amarelas, ca. 5,2 mm compr., fauce curto-campanulada, glabra, lobos ca. 2 mm compr. glabros. Cipselas subcilíndricas ca. $4 \times 1 \mathrm{~mm}$, rugosas, glabras; pápus ausente. Material selecionado: GOIÁS: Monte Alegre, IV.2003, fl. e fr., Fagg \& Oliveira 1270 (IBGE). TOCANTINS: Paranã, III.2004, fl. e fr., Sevilha et al. 3776 (CEN).

Brasil: GO, TO, PI e MA. Cerrado s.s. Flores em março e abril.

44. Tilesia baccata (L.) Pruski var. baccata, Novon 6: 414. 1996.

Arbustos ou subarbustos 0,4-2 m alt., serícios a estrigulosos. Folhas opostas, inteiras, ovais a elípticas, 4,1-14,1 × 1,9-8,3 cm, estrigosas, pecíolo 3-16 mm compr., ápice agudo a cuspidado, base atenuada a obtusa, margem serreada a serrilhada. Capítulos radiados, em tirsóides, 1-1,5 cm diâm., pedúnculo 7-20 mm compr.; invólucro hemisférico, 2-seriado; brácteas involucrais foliáceas, subiguais, linear-lanceoladas, estrigosas, ápice agudo; receptáculo plano, paleáceo; páleas conduplicadas, oblanceoladas, ápice agudo curto-ciliado, face dorsal pubérula. Flores do raio neutras, amarelas, tubo 0,7-1 mm compr., glabro ou esparso-setoso, limbo 6-72 mm compr., setoso na face abaxial; flores do disco monoclinas, amarelas, 4,6-5 mm compr., fauce cilíndrica a estreito-infundibuliforme, glabra, lobos ca. $1 \mathrm{~mm}$ compr., pubérulos. Cipselas obpiramidais, 2,8-3,6 × 1,3-2,5 mm, envolvidas por polpa carnosa globosa; pápus ausente.

Material selecionado: GOIÁS: São Domingos, III.2004, fl. Amaral-Santos et al. 2330 (CEN). TOCANTINS: Arraias, II.2006, fl. e fr., Bringel \& Barbosa 284 (CEN e UB).

América do Sul, América Central (Pruski 1996). Mata estacional decidual. Flores e frutos de fevereiro a março.
45. Tridax procumbens L., Sp. pl. 2: 900. 1753.

Ervas até $30 \mathrm{~cm}$ alt., procumbentes, hirsutas. Folhas opostas, inteiras, ovais, 13-36 $\times$ 5-14 mm, seríceas, sésseis, ápice agudo ou acuminado, base longo-atenuada, margem serrilhada a denteada. Capítulos radiados, em cimeiras assimétricas, 1,3-2 cm diâm., pedúnculo 4-12 cm compr.; invólucro hemisférico, 2-seriado; brácteas involucrais foliáceas, subiguais, oblongolanceoladas, seríceo-tomentosas, ápice agudo a acuminado; receptáculo plano, paleáceo; páleas levemente côncavas, lanceoladas, ápice agudo, face dorsal glabra. Flores do raio pistiladas, leve-amareladas, tubo 3-4 mm compr., hirsuto, limbo 3,5-4,5 mm compr., glabro; flores do disco monoclinas, amarelas, 6-6,8 mm compr., fauce estreito-cilíndrica, glabra, lobos ca. $1 \mathrm{~mm}$ compr., ciliados. Cipselas obovóides, ca. $2 \times 1$ mm, seríceas; pápus de cerdas plumosas, 4,5$7 \mathrm{~mm}$ compr.

Material selecinado: GOIÁS: Alvorada do Norte, VIII.2003, fl. e fr., Sevilha et al. 3149 (CEN).

Trópicos/subtrópicos. Introduzida na Europa, ornamental. Ambientes perturbados. Flores o ano todo (Powell 1965).

46. Viguiera bracteata Gardner, London. J. Bot. 7: 404. 1848.

Fig. $3 \mathrm{~m}, \mathrm{t}$

Subarbustos ou arbustos 0,8-1,5 m alt., glabros a estrigulosos. Folhas inteiras, alternas dísticas ou opostas, inteiras, lineares a lanceolato-elípticas, $16-140 \times 1-18 \mathrm{~mm}$, estrigulosas a glabrescentes, raramente glandulosopontuadas, sésseis, ápice acuminado, base truncada a cuneada, margem inteira a serrilhada. Capítulos radiados, em panículas corimbiformes, 1,2-2 cm diâm., pedúnculo 2-12 mm compr.; invólucro hemisférico, (3)4-seriado; brácteas involucrais, semifoliáceas desiguais, as internas maiores que as externas, lanceoladas a oblongas, estrigosas ou apenas ciladas, ápice agudo a acuminado; receptáculo convexo, paleáceo; páleas conduplicadas, oblongas, ápice obtuso, ciliado, face dorsal estrigulosa, glanduloso-pontuada no ápice. Flores do raio neutras, amarelas, tubo 1-2,3 mm compr., pubérulo, limbo 9-18 mm compr., glabrescente 
a estrigulosa na face abaxial; flores do disco monoclinas, amarelas, 5-6 mm compr., fauce cilíndrica, estrigulosa na base, lobos ca. $1 \mathrm{~mm}$ compr., glabros. Cipselas oblanceoladas, 3,4$4 \times 1-1,4$ mm seríceas; pápus 1-aristado, arista ereta, ca. $2 \mathrm{~mm}$ compr.; páleas $1-1,3 \mathrm{~mm}$ compr., ca. $3 / 4$ unidas.

Material selecionado: GOIÁS: Cavalcante, IV.2004, fl. e fr., Fonseca et al. 5124 (IBGE).

Brasil: MG, GO, MS, DF. Flores de janeiro a maio. Campo úmido ou seco e cerrado s.s. (Magenta 2006).

47. Viguiera filifolia Sch. Bip. ex Baker in Martius \& Eichler, Fl. bras. 6(3): 219. 1884.

Subarbustos 1-1,8 m alt., glabros. Folhas alternas, espiraladas, inteiras, filiformes, 51$156 \times 0$,7-2 mm, glabras, sésseis, ápice agudo, base truncada, margem inteira. Capítulos radiados, em botrióides, 1,1-2 cm diâm., pedúnculo 2-75 $\mathrm{mm}$ compr.; invólucro campanulado, 3-seriado; brácteas involucrais, semifoliáceas, levemente desiguais, linearlanceoladas a lanceoladas, glabrescentes a ciliadas, ápice agudo a cuspidado; receptáculo convexo, paleáceo; páleas conduplicadas, oblongo-oblanceoladas, ápice agudo, face dorsal estrigulosa na faixa central. Flores do raio neutras, amarelas, glabrescentes, tubo ca. 2 mm compr., limbo 1,4-2,1 cm compr.; flores do disco monoclinas, amarelas, 4-6 mm compr., fauce cilíndrica, pubérula na base, lobos ca. $1 \mathrm{~mm}$ compr., pubérulos. Cipselas obovais, 3-3,5 × 1,4-1,5 mm, seríceas; pápus 2aristado, aristas eretas, 2-3,2 mm compr.; páleas 1,2-1,6 mm compr., unidas até próximo ao ápice.

Material selecionado: GOIÁS: Alto Paraíso de Goiás, V.1994, fl. e fr., S. Bridgewater et al. 206 (UB).

Brasil: MG GO e BA (Magenta 2006). Campo e cerrado s.s. Flores e frutos de dezembro a fevereiro.

48. Viguiera gardneri Baker in Martius \& Eichler, Fl. bras. 6(3): 224. 1884 Fig. 2o

Subarbustos $80 \mathrm{~cm}$ alt., hirsutos. Folhas opostas na base, alternas dísticas na porção terminal, inteiras, oblongas, elípticas ou ovais 19-44 × 8-21 mm, estrigosas a híspidas, glanduloso-pontuadas, sésseis, ápice obtuso a mucronulado, base obtusa a truncada, margem inteira a serreada. Capítulos radiados, em botrióides corimbiformes, 1,4-2 cm diâm., pedúnculo 8,5-14 cm compr.; invólucro hemisférico, 4-seriado; brácteas involucrais semifoliáceas, desiguais, as internas maiores, ovais, estrigulosas, ápice agudo a obtuso; receptáculo convexo, paleáceo; páleas conduplicadas, oblongo-elípticas, ápice acuminado, face dorsal glabrescente, pruinosa. Flores do raio neutras, amarelas, tubo ca. 2 mm compr., hirtelo, limbo 8-17 mm compr., hirtelo na face abaxial; flores do disco monoclinas, amarelas, 4,5-5,5 mm compr., fauce cilíndrica, estrigulosa na base, lobos ca. $1 \mathrm{~mm}$ compr., estrigulosos. Cipselas estreitoobovais a oblanceoladas, 3,9-4,5 ×1-1,4 mm, seríceas; pápus 1-aristado, arista ereta, ca. 2,5 $\mathrm{mm}$ compr.; escamas ca. 1,5 mm compr., unidas da metade até próximo ao ápice.

Material examinado: GOIÁS: Cavalcante, IV.2004, fl. e fr., Fonseca et al. 5514 (IBGE).

Brasil: GO, MG e DF (Magenta 2006). Campo sujo. Flores e frutos em abril.

49. Viguiera grandiflora (Gardner) Gardner, London J. Bot. 7: 404. $1848 . \quad$ Fig. 2q

Ervas a subarbustos $30-80 \mathrm{~cm}$ alt., glabras a esparso-hirsutas. Folhas alternodísticas ou opostas, inteiras, ovais, elípticas, oblongas ou obovais, 4,4-11,5 × 1,7-7,5 cm, estrigosas a híspidas, ocasionalmente glanduloso-pontuadas, sésseis, ápice agudo a obtuso, base cuneada a truncada, serrilhada a serreada. Capítulos radiados, solitários ou em corimbos laxos, 20-35 mm diâm., pedúnculo 9-19 cm compr.; invólucro hemisférico, 2seriado; brácteas involucrais escariosas, subiguais, estreito-lanceoladas, estrigosas, ápice acuminado a caudado; receptáculo convexo, paleáceo; páleas conduplicadas, oblongolanceoladas, ápice acuminado, face dorsal estrigosa. Flores do raio neutras, amarelas, tubo ca. 2 mm compr., estriguloso; limbo 1,8-3,3 
cm compr., estriguloso na face abaxial; flores do disco monoclinas, amarelas, ca. $6 \mathrm{~mm}$ compr., fauce cilíndrica, estrigulosas, lobos 1,21,5 mm compr., estrigulosos. Cipselas obovais a oblanceoladas, 5,8-8,4 ×2-3,4 mm, estriadas, glabras a hispidulosa; pápus 2-aristado, aristas eretas, 0,8-2 mm compr.; páleas reduzidas ou até $1 \mathrm{~mm}$ compr., unidas até a metade.

Material examinado: GOIÁS: Alto Paraíso de Goiás, XI.2004, fl. e fr., Pastore \& Suganuma 1076(CEN); TOCANTINS: Arraias, XI.1991, fl. e fr., Hatschbach et al. 56012 (NY).

Brasil. MS, GO, TO, DF (Magenta 2006). Cerrado s.s. Flores e frutos em novembro.

50. Viguiera kunthiana Gardner, London J. Bot. 7: 399. 1848.

Ervas a subarbustos 50-70 cm alt., setosas a estrigosas. Folhas alternas dísticas, raramente opostas, inteiras, lineares, 23-105 ×2-4 mm, estrigosas a híspidas, sésseis, ápice mucronulado, base truncada, margem inteira. Capítulos solitários ou em botrióides laxos, 1,31,5 cm diâm., pedúnculo 1-22 cm compr.; invólucro hemisférico, 2-seriado; brácteas involucrais, foliáceas, subiguais, ovais a elípticas, estrigosas, ápice agudo; receptáculo convexo, paleáceo; páleas conduplicadas, oblongo-elípticas, ápice agudo a obtuso, face dorsal pubérula. Flores do raio neutras, amarelas, tubo 1-1,5 mm compr., hispiduloso; limbo 1,7-1,9 cm compr. glabrescente a hirtelo na face abaxial; flores do disco monoclinas, amarelas, 3,2-4,3 mm compr., fauce cilíndrica, esparso-estrigulosas, lobos 0,8-1 mm compr., estrigulosos. Cipselas obovais, 2,9-3,8 × 1,3$2 \mathrm{~mm}$, estrigulosas no ápice; pápus 2-aristado, aristas eretas, 1,3-2,5 mm compr., unidas às páleas; escamas 0,8-1,7 mm compr.

Material examinado: GOIÁS: Alto Paraíso de Goiás, XI.2004, fl., Pastore \& Suganuma 1075 (CEN).

Brasil: GO, MG e DF (Magenta 2006). Campos limpos. Flores em novembro.

51. Viguiera oblongifolia Gardner, Lond. J. Bot. 7: 404. 1848.

Fig. 2n

Ervas a subarbustos $50-70 \mathrm{~cm}$ alt., cespitosas, pruinosas, estrigosas a hirsutas.
Folhas opostas ou alterno-dísticas, inteiras, oblongas, elípticas, lanceoladas, 25-85×5-20 $\mathrm{mm}$, estrigosas a híspidas, sésseis, ápice acuminado a mucronado, base cuneada, margem inteira. Capítulos radiados, em botrióides corimbiformes, 7-12 mm diâm., pedúnculo 17-28 cm compr.; invólucro campanulado, 4-seriado; brácteas involucrais semifoliáceas, desiguais, as mais externas iguais ou menores que a metade das internas, ovais a oblongas, estrigulosas ou ciliadas, ápice cuspidado; receptáculo convexo, paleáceo; páleas conduplicadas, oblongas, ápice acuminado a caudado, face dorsal estrigulosa. Flores do raio neutras, amarelas, tubo 1-1,8 mm compr., tricomas esparsos, limbo 1,3-1,8 cm compr., glabro; flores do disco monoclinas, amarelas, 4,5-5,5 $\mathrm{mm}$ compr., fauce infundibuliforme, estrigulosa, lobos 0,8-1,2 mm compr., estrigulosos. Cipselas oblanceoladas, 5-6×1,3-1,6 mm, glabrescentes a pubérulas; pápus 1-2-aristado, aristas eretas, 2-2,7 mm compr., escamas 1-1,5 mm compr., unidas até a metade.

Material selecionado: GOIÁS: Teresina de Goiás, I.2006, fl. e fr.,Pastore \& Suganuma 1423 (CEN).

Brasil: Central, CE, MA, PA, TO (Magenta 2006). Campo de murundus e limpo. Flores e frutos de janeiro a março.

52. Wedelia modesta Baker in Martius \& Eichler, Fl. bras. 6(3). 185. 1884.

Ervas eretas, ca. $1 \mathrm{~m}$ alt., hirsutas. Folhas opostas, inteiras, ovais, 6,6-12,2 2 2,2-5,4 cm, pubescentes a hirsutas apenas nas nervuras, pecíolo 9-12 mm compr., ápice cuspidado, base atenuada, margem crenada a serrilhada. Capítulos radiados, em dicásios, 10-12 cm diâm., pedúnculo 3,5-5,3 cm compr.; invólucro hemisférico, 2-seriado; brácteas involucrais semifoliáceas, subiguais, ovais, estrigosas, com pontuações negras, ápice agudo; receptáculo convexo, paleáceo; páleas conduplicadas, oblanceoladas, ápice agudo, esparsamente ciliado, face dorsal glabrescente. Flores do raio pistiladas, amarelas, glabras, tubo ca. 1,5 mm 
compr., limbo 7,5 mm compr.; flores do disco monoclinas, amarelas, ca. 3,3 mm compr., fauce infundibuliforme a campanulada, glabra, lobos ca. 0,7 mm compr., glabros. Cipselas obovais, ca. $3 \times 2 \mathrm{~mm}$, tricomas esparsos; pápus de escamas em estrutura coroniforme, ca. 0,3 mm compr.

Material examinado: GOIÁS: Alvorada do Norte, III.1979, fl. e fr., Hatschbach 42018 (NY).

Brasil: GO e MG (Baker 1884). Flores e frutos em março.

53. Wedelia pallida Gardner, London J. Bot. 7: 288.1848 Fig. 3g, $n$

Subarbustos $50-80 \mathrm{~cm}$ alt., cespitosos, híspidos. Folhas opostas, inteiras, elípticas a lanceoladas, 7-10,8 × 2,6-4 cm, estrigosas, glanduloso-pontuadas na face abaxial, sésseis, ápice agudo, base obtusa a truncada a levecordada; margem denteada a serrilhda. Capítulos radiados, em tirsóides, 1-2(3) por nó terminal, 8-12 mm diâm., pedúnculo 1-46 mm compr.; invólucro campanulado a hemisférico, 2seriado; brácteas involucrais foliáceas, subiguais, ovais, estrigosas a tomentosas, glandulosopontuadas, ápice agudo a cuspidado; receptáculo convexo, paleáceo; páleas conduplicadas, oblanceoladas, ápice mucronado, ciliado, face dorsal esparso-estrigosa, glanduloso-pontuada. Flores do raio pistiladas, alvas, tubo ca. $1 \mathrm{~mm}$ compr., setoso, limbo ca. 5,5 mm compr., glanduloso-pontuado na face abaxial; flores do disco monoclinas, amarelas, 3-4 mm compr., fauce cilíndrica a estreito-infundibuliforme, esparso-setosa a glabra, lobos ca. 0,5 mm compr., glanduloso-pontuados. Cipselas obovóides a elipsóides, 4-4,6 × 2,5-3 mm, verrucosas a quase lisas; pápus de escamas em estrutura coroniforme 0,2-05 mm compr. Material examinado: GOIÁS: Monte Alegre, III.2006, fl. e fr., Bringel \& Barbosa 299 (CEN, UB).

Bolívia, Paraguai e Brasil: RS, PR, SP, MS, MG, GO. Cerrado s.s. Flores e frutos em março. Baker (1884) cita W. pallida como sinônimo de W. macrodonta DC. No entanto, a foto do material-tipo de $W$. macrodonta, não parece representar $W$. pallida. Este fato já havia sido observado por Robinson (1984).
54. Wedelia regis $\mathrm{H}$. Rob., Phytologia 55(6): 399. 1984.

Fig. 2s; 3c, v

Subarbustos 50-70 cm alt., cespitosos, pubérulos a tomentosos. Folhas opostas, inteiras, ovais a lanceoladas, raramente elípticas, 14-95 × 6-49 mm, estrigosas a tomentosas, glanduloso-pontuadas na face abaxial, pecíolo até $5 \mathrm{~mm}$, raramente sésseis, ápice agudo a obtuso, base obtusa, margem serreada, raramente crenada. Capítulos radiados, em dicásios simples ou tirsóides, (1)35 por nó terminal, 7-17 mm diâm., pedúnculo 3-27 mm compr.; invólucro hemisférico, 2seriado; brácteas involucrais foliáceas, subiguais, ovais a obovais, estrigosas a tomentosas, glanduloso-pontuadas, ápice agudo, raro obtuso; receptáculo convexo, paleáceo; páleas conduplicadas, oblanceoladas, ápice agudo, ciliado; face dorsal estrigosa, glandulosa-pontuada. Flores do raio pistiladas, amarelas, tubo ca. $1 \mathrm{~mm}$ compr., hirtelo, limbo 5,5-6,5 mm compr., setoso e glandulosopontuado na face abaxial; flores do disco monoclinas, amarelas, 3,6-4,3 mm compr., fauce cilíndrica a estreito-infundibuliforme, esparso-setosa a glabra, lobos ca. 0,5 mm compr, setosos a glabros, glandulosopontuados; receptáculo convexo, paleáceo. Cipselas obovóides a elipsóides, 3,9-4,3×2-3 $\mathrm{mm}$, setosas a glabrescentes; pápus em estrutura coroniforme 0,3-0,6 mm compr.

Material selecionado: GOIÁS: Campos Belos, II.2006, fl. e fr., Bringel \& Barbosa 293(CEN, UB); TOCANTINS: Arraias, II.2006, fl. e fr., Bringel \& Barbosa 280 (CEN, UB).

Brasil: MG, GO, DF e TO. Cerrado s.s. Flores e frutos em fevereiro. A análise do material-tipo de Wedelia vauthieri DC. sugere uma proximidade desta espécie com $W$. regis. Entretanto, W. vauthieri apresenta capítulos solitários e flores do raio com limbo aparentemente maior. Além disto, Baker (1884) não descreve $W$. vauthieri apresentando capítulos solitários e sim em estruturas corimbiformes. É necessário um melhor estudo das duas espécies, com observação de materiais-tipo, a fim de verificar se são sinônimos, já que os capítulos solitários 
mostrados no tipo de W. vauthieri pode representar apenas o estágio inicial de uma inflorescência mais complexa e o limbo das flores do raio maior apenas um extremo de variação morfológica.

55. Wedelia souzae H. Rob., Phytologia 55(6): 401. 1984. Fig. 2t-v

Arbustos 1-1,6 m alt., estrigosos ou glabros. Folhas opostas, inteiras, ovais a lanceoladas, 18-68 × 5-25 mm, estrigosas a esparso-tomentosas, glanduloso-pontuadas na face abaxial, pecíolo 1-8 mm compr., ápice agudo, base obtusa, margem serrilhada a serreada. Capítulos radiados, isolados, 1 por nó terminal, 8-114 mm diâm., pedúnculo 1,87,5 cm compr.; invólucro campanulado a hemisférico, 2-seriado; brácteas involucrais foliáceas, subiguais, ovais, estrigosas, glanduloso-pontuadas, ápice agudo; receptáculo convexo, paleáceo; páleas conduplicadas, oblanceoladas, ápice acuminado, ciliado, face dorsal glabra ou glabrescente, raramente inconspicuamente glanduloso-pontuada. Flores do raio pistiladas, amarelas, tubo 0,5-0,8 mm compr., setoso, limbo 6-9 mm compr., setoso e glandulosopontuado na face abaxial; flores do disco monoclinas, amarelas, 4-5 mm compr., fauce cilíndrica a infundibuliforme, esparso-setosa a glabra, lobos ca. 0,5 mm compr., glandulosopontuados. Cipselas obovóides a elipsóides, 2,8-3,9 × 1,9-2,7 mm, lisas a fortemente rugosas, setosas no ápice; pápus de escamas em estrutura coroniforme 0,5-0,8 mm compr. Material selecionado: GOIÁS: Alto Paraíso de Goiás, XI.1976, fl. e fr., Shepherd et al. 3749(MBM).

Brasil: Chapada dos Veadeiros. Campos úmidos, matas de galeria. Flores e frutos de outubro a março.

\section{Agradecimentos}

Aos curadores dos herbários visitados, Gert Hatschbach, Marina de Lourdes Fonseca, Jackie Kallunki, Wayt Thomas e funcionários, ao Jimi Nakajima, Carolyn Proença e Bruno Walter pelas contribuições, ao John Pruski pelas bibliografias, ao Sérgio Noronha pela confecção do mapa, à Embrapa/Cenargen e ao PROTAX/CNPq, pelas bolsas concedidas ao primeiro autor; João B. A. Bringel Jr. é bolsista FUNARBE e Taciana B. Cavalcanti é Bolsista PQ/CNPq n ${ }^{\circ}$ 300976/95-0

\section{REFERÊNCIAS BIBLIOGRÁFICAS}

Arriagada, J. E. 2003. Revision of the genus Clibadium (Asteraceae, Heliantheae). Brittonia 55(3): 245-301.

Baker, H. G. 1965. Characteristics and modes of origin of weeds. In: Baker, H. G. \& Stebbins, G. L. (eds.). The genetics of colonizing species. Academic Press, London. Pp. 147-169.

Baker, J. G. 1884. Compositae IV. HelianthoideaeMutisiaceae. In: Martius, C. F. P. \& Eichler, A. W. (ed.). Flora brasiliensis. Vol. 6, pars 3. München, Wien, Leipzig. Pp. 138-298.

Baker, J. G. 1889. Icones plantarum, or Figures, with brief descriptive characters and remarks, of new or rare plants, selected from the Kew herbarium 19: pl. 1825.

Barroso, G. M.; Peixoto, A. L.; Ichaso, C. L. F.; Costa, C. G.; Guimarães, E. F. \& Lima, H.C. 1991. Sistemática de angiospermas do Brasil. Vol. 3. Imprensa Universitária, Universidade Federal de Viçosa, Viçosa. Pp. 237-314.

Blake S. F. 1921. Revision of the genus Acanthospermum. Contributions from United States National Herbarium 29: 383-392.

Jansen, K. R. 1981. Systematic of Spilanthes (Compositae-Heliantheae). Systematic Botany 6: 231-257.

Jansen, K. R. 1985. Systematic of Acmella (Asteraceae Heliantheae). Systematic Botany Monographs 8: 1-115.

Karis, P. O. \& Ryding O. 1994. Tribe Heliantheae. In: Bremer, K. (ed.). Asteraceae. Cladistics and classification. Timber Press, Portland. Pp. 559-625.

Magenta, M. A. G. 2006. Viguiera Kunth (Asteraceae, Heliantheae) na América do Sul e sistemática das espécies do Brasil. 
Tese de Doutorado. Universidade de São Paulo, São Paulo. 339p.

MMA. 2007. Áreas prioritárias para conservação, uso sustentável e repartição de benefícios da biodiversidade brasileira: Atualização - Portaria MMA n ${ }^{\circ}$ 09, de 23 de janeiro de 2007. Ministério do Meio Ambiente, Secretaria de Biodiversidade e Florestas, Brasília. 299p.

Moraes, M. D.; Panero, J. L. \& Semir, J. 2007. New combinations in Dimerostemma (Asteraceae: Heliantheae-Ecliptinae). Phytologia 89: 115-120.

Nakajima, J. N. \& Semir, J. 2001 Asteraceae do Parque Nacional da Serra da Canastra, Minas Gerais, Brasil. Revista Brasileira de Botânica 24: 471-478.

Panero, J. L. \& Funk, V. A. 2008. The value of sampling anomalous taxa in phylogenetic studies: Major clades of the Asteraceae revealed. Molecular Phylogenetics and Evolution 47: 757-782.

Pereira, R. C. A. 2001. Revisão taxonômica do gênero Ichthyothere Mart. (HeliantheaeAsteraceae). Tese de Doutorado. Universidade Federal Rural de Pernambuco, Recife. 211p.

Powell, A. M. 1965. Taxonomy of Tridax (Compositae). Brittonia 17: 47-96.

Pruski, J. F. 1996. Compositae of the Guayana Highland - XI. Tuberculocarpus gen. nov. and some other Ecliptinae (Heliantheae). Novon 6: 404-418.

Pruski, J. F. 1998. Compositae of Guayana Highland - XII. New combinations in Conyza (Astereae), Praxelis (Eupatorieae), and Riencourtia (Heliantheae) based on names proposed by L.C.M. Richard. Brittonia 50: 473-482.

Pruski, J. F. \& Urbatsch L. E. 1987. Calea dalyi (Compositae: Heliantheae), a new species from the Serrania de Santiago, Bolivia. Brittonia 39: 201-204.

Pruski, J. F. \& Urbatsch L. E. 1988. Five species of Calea (Compositae: Heliantheae) from Planaltine Brazil. Brittonia 40: 341-356.
Robinson, H. 1978. Studies in the Heliantheae (Asteraceae). XV. Various new species and combinations. Phytologia 41: 33-38.

Robinson, H. 1981. A revision of tribal and subtribal limits of the Heliantheae (Asteraceae). Smithsonian Contributions to Botany 51: 1-102.

Robinson, H. 1984. Studies in the Heliantheae (Asteraceae). XXXII. New species of Wedelia from Brazil. Phytologia 55: 389-414.

Rua, G. H. 1999. Inflorescencias. Bases teóricas para su análisis. Sociedad Argentina de Botánica, Buenos Aires. 100p.

Santos, J. U. M. 2001. O gênero Aspilia Thou. (Asteraceae/Heliantheae) no Brasil. Museu Paraense Emílio Goeldi, Belém. 303p.

Sherff, E. E. 1932. Revision of the genus Cosmos. Publications of the Field Columbian Museum, Botanical Series 8: 399-448.

Sherff, E. E. 1937. The genus Bidens. Field Museum of Natural History, Botanical Series 16: 1-485.

Silva L. A. \& Scariot A. 2004. Comunidade de uma floresta estacional decídua sobre afloramento calcáreo na bacia do rio Paranã. Revista Árvore 28: 61-67.

Stuessy, T. F. 1970. The genus Acanthospermum (Compositae-Helinatheae-Melampodinae): Taxonomic changes and generic affinibties. Rhodora 72: 106-109.

Stuessy, T. F. 1972. Revision of genus Melampodium (Compositae: Heliantheae). Rhodora 74: 1-70.

Stuessy, T. F. 1973. Revision of genus Baltimora (Compositae: Heliantheae). Fieldiana 36: 31-50.

Turner, B.L. 1988. Taxonomic study in Chrysanthellum (Asteraceae). Phytologia 64: 410-444.

Urbatsch, L. E.; Zlotsky, A. \& Pruski, J. F. 1986. Revision of Calea sect. Lemmatium (Asteraceae: Heliantheae) from Brazil. Systematic Botany 11(4): 501-504. 


\section{ISTA DE EXSICATAS}

Amaral-Santos, A. et al. 2261 (32); 2330 (44); 2408 (7); Anderson, W.R. 6496 (38); 6594 (46); 6880 (44); 6900 (31); 7195(8); 7310 (14); Aparecida-Silva, M. \& Santos, A.J.V. 3241 (16); 3269 (16); 3272 (35); Aparecida-Silva, M. et al. 2011 (26); 3387 (5); 3394 (37); 4307 (7); 4309 (31); 4370 (30); 4847 (32); 4901 (6); Barroso G 544 (5); Belém, R.P. \& Mendes, J.M. 101(1); 98 (15); Bridgewater, S. et al. 196 (33); 197 (20); 206 (47); Bringel, J.B.A. \& Barbosa, N.F. 270 (44); 280 (54); 281 (3); 282 (40); 284 (44); 288 (39); 289 (30); 290-B (28); 293 (54); 295 (40); 299 (53); 310 (15); Bringel, J.B.A.et al. 44* (50); 80* (23); 82* (27); 85* (55); 93 (35); 106* (25); 194* (49); 244* (37); 397 (20); Calago, K. 100 (11); 102 (19); Cavalcanti, T.B.et al. 1292 (54); 1326 (11); 3444 (5); Fonseca, M.L. et al. 1302 (42); 2261 (13); 2498 (41); 2500 (26); 26 (6); 4144 (41); 4275 (51); 4376 (29); 5033 (27); 5040 (26); 5124 (46); 5127 (37); 5138 (17); 5348 (19); 5514 (48); 2514 (1); Ginsbarg, S. \& César, P. 751 (23); Guarino, E.S.G. et al. 443* (5); Hatschbach, G 70899 (43); 71145 (41); Hatschbach, G et al. 39412 (4); 42014 (4); 42018 (53); 42024 (41); 54690 (5); 54692 (41); 56012 (39); 70687 (32); 70825 (31); 70858 (18); 70864 (3); 70936 (22); 70993 (32); 71001 (17); 71018 (26); 71033 (29); 71070 (4); 71155 (24); 60413 (2); Heringer E.P. $1207 *$ (14); Irwin, H.S.et al. 14270 (30); 14370 (37); 14592 (9); 15141 (34); 15220 (30); 32791 (48); 32903 (25); King, R.M. \& Bishop, L.E. 8798 (10); 8799 (32); 8800 (39); 8823 (56); Mendonça, R.C. et al. 4140 (12); 4539 (5); 5238 (28); 5309 (26); 5363 (28); 5364 (21); 5395 (36); 5411 (36); 5433 (40); 5463 (11); Munhoz, C.B. et al. 1150 (19); 1243 (19); 1414 (19); 1773 (19); Oliveira, F.C.A. et al. 78 (5); 1103 (2); Pastor, J.F. \& Bringel, J.B.A. 687* (5) Pastore, J.F. \& Suganuma, E. 1071 (16); 1075 (50); 1076 (49); 1085 (5); 1423 (51); Pereira-Silva G et al. 6036* (10); Sevilha,A.C.et al. 2093 (44); 3149 (45); 3314 (45); 3602 (19); 3726 (17); 3775 (21); 3776 (43); 3850 (21); 4125(18); Shepherd, G. et al. 3749 (55); 3751 (55); Walter, B.M.T. et al. 2126 (38); 4693* (34); 4915* (6).

Obs.: * material adicional examinado 